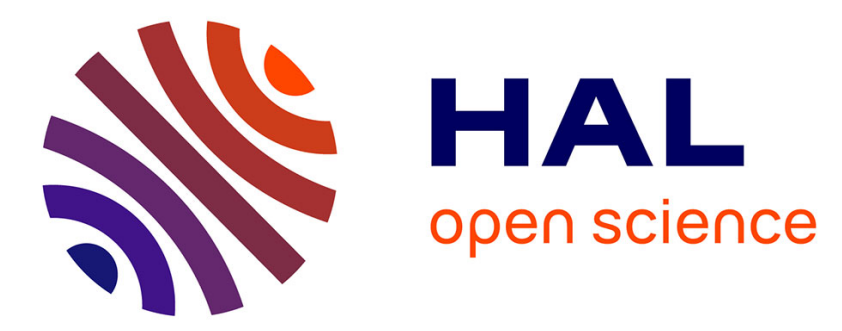

\title{
Effect of corrosion on the fatigue life and fracture mechanisms of 6101 aluminum alloy wires for car manufacturing applications
}

Adrien Laurino, Eric Andrieu, Jean-Paul Harouard, Grégory Odemer, Jean-Claude Salabura, Christine Blanc

\section{To cite this version:}

Adrien Laurino, Eric Andrieu, Jean-Paul Harouard, Grégory Odemer, Jean-Claude Salabura, et al.. Effect of corrosion on the fatigue life and fracture mechanisms of 6101 aluminum alloy wires for car manufacturing applications. Materials \& Design, 2014, vol. 53, pp. 236-249. 10.1016/j.matdes.2013.06.079 . hal-01168963

\section{HAL Id: hal-01168963 https://hal.science/hal-01168963}

Submitted on 26 Jun 2015

HAL is a multi-disciplinary open access archive for the deposit and dissemination of scientific research documents, whether they are published or not. The documents may come from teaching and research institutions in France or abroad, or from public or private research centers.
L'archive ouverte pluridisciplinaire HAL, est destinée au dépôt et à la diffusion de documents scientifiques de niveau recherche, publiés ou non, émanant des établissements d'enseignement et de recherche français ou étrangers, des laboratoires publics ou privés. 


\section{OATAO \\ Open Archive Toulouse Archive Ouverte}

\section{Open Archive TOULOUSE Archive Ouverte (OATAO)}

OATAO is an open access repository that collects the work of Toulouse researchers and makes it freely available over the web where possible.

This is an author-deposited version published in : http://oatao.univ-toulouse.fr/ Eprints ID : 14021

To link to this article : DOI:10.1016/j.matdes.2013.06.079

URL : http://dx.doi.org/10.1016/j.matdes.2013.06.079

To cite this version : Laurino, Adrien and Andrieu, Eric and Harouard, Jean-Paul and Odemer, Grégory and Salabura, Jean-Claude and Blanc, Christine Effect of corrosion on the fatigue life and fracture mechanisms of 6101 aluminum alloy wires for car manufacturing applications. (2014) Materials \& Design, vol. 53. pp. 236-249. ISSN 0261-3069

Any correspondance concerning this service should be sent to the repository administrator: staff-oatao@,listes-diff.inp-toulouse.fr 


\title{
Effect of corrosion on the fatigue life and fracture mechanisms of 6101 aluminum alloy wires for car manufacturing applications
}

\author{
A. Laurino a,b, E. Andrieu a , J.-P. Harouard ${ }^{\text {b }}$, G. Odemer ${ }^{\mathrm{a}, *}$, J.-C. Salabura ${ }^{\mathrm{a}}$, C. Blanc ${ }^{\mathrm{a}}$ \\ a Université de Toulouse, CIRIMAT, UPS/CNRS/INPT, 4 allée Emile Monso, BP 44362, 31030 Toulouse Cedex 4, France \\ ${ }^{\mathrm{b}}$ Leoni Wiring Systems France, 5 Avenue de Newton, 78180 Montigny-le-Bretonneux, France
}

\begin{abstract}
A B S T R A C T
An innovative solution for the automotive industry is to replace the copper used for wiring harnesses with aluminum alloys, such as the aluminum-magnesium-silicon 6101 alloy. Wiring harnesses are composed of thin strand arms obtained by a wire drawing process. These strands are susceptible to exposure to a corrosive environment and fatigue solicitations simultaneously. The fatigue endurance of this alloy was studied using the stress-life approach for three metallurgical states representative of three colddrawing steps. Fatigue tests performed in corrosive media tests highlighted a strong decrease of the 6101 alloy lifetime due to fatigue-corrosion interactions and a modification of failure modes.
\end{abstract}

\section{Introduction}

Considering the rarefaction of fossil fuels and the need to reduce greenhouse gas emissions, automotive manufacturers are looking for innovative solutions to reduce both the cost and weight of wiring harnesses. One promising solution is the substitution of copper with aluminum alloys, such as the aluminummagnesium-silicon 6101 alloy, which is currently used for highpower electrical applications. Wiring harnesses require thin strand arms, which are obtained by wire-drawing. This metalworking process consists of a reduction in the rod or wire diameter by passing it through a series of drawing dies interspersed, if necessary, with aging heat treatments to release the stresses induced by the process. The different microstructures obtained after each step of the manufacturing process strongly depend on the thermomechanical process characteristics, which also affect the mechanical properties and the corrosion behavior of the material. The strands are susceptible to exposure to several corrosive environments, e.g., de-icing road salt, coolant, and windshield washer fluids, and fatigue solicitations due to motor and engine vibrations. These combined damages can lead to a premature degradation of wiring harnesses. Many studies have focused on the role of pre-corrosion damage on the residual fatigue life and the effect of localized corrosion defects on fatigue crack initiation in aluminum alloys. Most such studies have focused on the 2xxx and 7xxx series and fatigue crack initiation from pitting corrosion defects

\footnotetext{
* Corresponding author. Tel.: +33 (0)5 343234 38; fax: +33 (0)5 34323498 . E-mail address: gregory.odemer@ensiacet.fr (G. Odemer).
}

[1-11]. These alloys have shown a large reduction in fatigue life due to corrosion pits, providing potential stress concentrator sites at which fatigue cracks can initiate. The pit size (average depth and width) seems to be an essential parameter; the fatigue life is successfully predicted by 2D AFGROW (Fracture Mechanics and Fatigue Crack Growth Analysis software tool) calculations based on initial crack sizes similar to those of pits [4]. Dolley et al. have shown, for AA 2024-T3, that the fatigue lives were reduced by more than one order of magnitude after $384 \mathrm{~h}$ of precorrosion in a $0.5 \mathrm{M} \mathrm{NaCl}$ solution compared to those of uncorroded specimens. The reduction of fatigue life was related to the time of exposure to the corrosive environment and pit size [11]. Burns et al. have shown that the fatigue life of a 7075-T6511 alloy was reduced substantially by EXCO pre-corrosion, but this was nearly independent of exposure time after initial-sharp degradation, scaling with the evolution of pit-cluster size and initial stress intensity range [12]. Liao et al. have studied the remaining fatigue life of 7075-T6511 aircraft wing skins containing natural exfoliation corrosion. It was found that the relative humidity did not have a significant effect on the fatigue life of naturally exfoliated specimens. Exfoliation above a "critical" level (undetermined in the paper of Liao et al. due to the limited number of tests) could significantly decrease the fatigue life of the naturally exfoliated specimens. When the exfoliation damage is not very severe, the discontinuities present in the fillet of the samples, where the stress concentration Kt was equal to 1.23 , could override the exfoliation damage and become the primary crack origin. Above the "critical" level, the cracks primarily nucleated from corrosion pits and intergranular corrosion defects [13]. Pauze has studied fatigue 
crack initiation on localized corrosion defects for a 2024-T351 aluminum alloy, i.e., intergranular corrosion defects and pits. Both defects acted as preferential initiation sites for transgranular fatigue cracks [14].

Finally, the fatigue life duration for pre-corroded samples is essentially related to the fatigue crack initiation step on preexisting localized corrosion defect. A possible effect of H-uptake during pre-corrosion treatment on crack propagation rates is possible but it is probably negligible compared to the strong decrease of the duration of the crack initiation step.

However, for the tests performed directly in the corrosive media, the same conclusion cannot be advanced seeing that corrosion and fatigue mechanisms could interact as well during crack initiation as during crack propagation.

Most of literature results about fatigue-corrosion interactions have shown that the reduction in the fatigue life in $\mathrm{NaCl}$ solutions could be attributed to premature crack initiation from surface corrosion defects [15-17].

The characteristics of these localized corrosion defects such as pit geometry $[18,19]$, micro-topographic strain concentration and local stress distribution around pit [20] are essential in determining the pit-to-crack transition such as fatigue life tests performed on pre-corroded samples. Mutombo and du Toit have characterized the fatigue-corrosion endurance behavior of a welded 6061-T651 aluminum alloy in a $3.5 \%$ (by weight) $\mathrm{NaCl}$ solution at various applied stress amplitudes [21]. The reduction in the fatigue life in the corrosive solution compared to the fatigue life in air was also most strongly related to the presence of pits, which nucleated on second-phase particles or precipitates and acted as preferential fatigue crack initiation sites. Pauze [14] has shown for a 2024 aluminum alloy that fatigue-corrosion interactions only acted on the crack propagation regime. The crack initiation occurred on corrosion defects which were strictly the same as those obtained during continuous immersion in corrosive media without applied stress. The effect of fatigue corrosion synergy only occurred during the crack propagation with the competition between the growth rate of the transgranular fatigue-corrosion crack and the growth rate of the intergranular stress corrosion crack. The propagation rate of the intergranular corrosion defect whose kinetic is relatively important during the first hours is quickly followed by a slow transgranular fatigue-corrosion propagation. The effect of the corrosive media is relatively low (factor 2-5) during this second step and occurs for low $\Delta K$ values. Finally transgranular fatigue-corrosion propagation is comparable to the propagation obtained in air [14].

In the present work, the reference metal was a $9.5 \mathrm{~mm}$ wire rod of AA 6101 (T4 metallurgical state); this rod was cold-drawn to manufacture the strand arms. The steps of the cold-drawing process used in the industry are summarized in Fig. 1. An intermediate aging heat treatment $\left(185^{\circ} \mathrm{C}-10 \mathrm{~h}\right)$ following the cold-drawing from a $9.5 \mathrm{~mm}$ diameter wire rod to a $1.34 \mathrm{~mm}$ diameter strand was applied. Finally, a final cold-drawing step provides a thin strand with a $0.51 \mathrm{~mm}$ final diameter (T9 metallurgical state). The influence of a pre-corrosion step on the fatigue and fatiguecorrosion behaviors of both T4 (the initial material) and T9 (the metallurgical state used) samples were studied. In parallel, some T4 samples were aged at $185^{\circ} \mathrm{C}$ for $10 \mathrm{~h}$ in the laboratory to specifically study the influence of the intermediate heat treatment $\left(\mathrm{T} 4+185^{\circ} \mathrm{C}-10 \mathrm{~h}\right)$ on the material properties.

In a previous work [22], the corrosion behavior of the aluminum-magnesium-silicon 6101 alloy has been studied in chloride solution in terms of the different metallurgical states resulting from the wire drawing process $\left(\mathrm{T} 4, \mathrm{~T} 4+185^{\circ} \mathrm{C}-10 \mathrm{~h}\right.$, and $\mathrm{T} 8$ metallurgical states; T8 corresponds to $\mathrm{T} 4+$ cold drawing until a $1.34 \mathrm{~mm}$-diameter rod was obtained, followed by the $185^{\circ} \mathrm{C}$ $10 \mathrm{~h}$ aging treatment; T9 corresponds to the same procedure as T8 except with an additional cold drawing step, which does not modify the corrosion morphology observed compared to the T8 state). Regardless of its metallurgical state, AA 6101 was found to be susceptible to localized corrosion. Scanning electron microscopy (SEM) observations of the electrode surfaces obtained after potentiokinetic polarization tests have shown that all metallurgical states were susceptible to two types of localized corrosion morphologies, i.e., pitting corrosion (Fig. 2(a) and (d)) and matrix dissolution around particles (Fig. 2(b)). Many thin corrosion filaments were observed around and between pit cavities according to literature results (Fig. 2(a) and (d)) [23]. These observations are consistent with the literature results. The main intermetallics present in $\mathrm{Al}-\mathrm{Mg}-\mathrm{Si}-\mathrm{Fe}$ alloys are Fe-rich particles such as $\mathrm{Al}_{3} \mathrm{Fe}$, $\alpha-\mathrm{Al}_{8} \mathrm{Fe}_{2} \mathrm{Si}, \beta-\mathrm{Al}_{5} \mathrm{FeSi}$ and $\pi-\mathrm{Al}_{8} \mathrm{FeMgSi}_{6}[24-26]$ and $\mathrm{Mg}_{2} \mathrm{Si}$ precipitates [27].

Pits in $\mathrm{Al}-\mathrm{Mg}-\mathrm{Si}$ alloys often initiate on intermetallic particles. Blanc et al. [28] have demonstrated using interferometry and surface observations that $\mathrm{Mg}_{2} \mathrm{Si}$ particles suffer preferential Mg dissolution just after a few seconds of immersion in aggressive media, in agreement with other authors [29,30]. Preferential initiation for deep corrosion was then observed at $\mathrm{Mg}_{2} \mathrm{Si}$ sites [28]. Concerning $\mathrm{Al}-\mathrm{Fe}-\mathrm{Si}$ precipitates, they are known to be cathodic respective to the aluminum matrix [26,31]. During immersion in an aggressive media, the galvanic cells created between these intermetallics and the matrix initiate the dissolution of the surrounding matrix [32].

For the $\mathrm{T} 4+185^{\circ} \mathrm{C}-10 \mathrm{~h}$ metallurgical state only, observations of the electrode surfaces revealed a third form of localized corrosion, i.e., intergranular corrosion (Fig. 2(c)). As a reminder, for $\mathrm{T} 4+185^{\circ} \mathrm{C}-10 \mathrm{~h}$, numerous precipitates arrange into a continuous film, with needle (average dimension $=35 \mathrm{~nm} \times 140 \mathrm{~nm}$ ) or globular shapes observed at the grain boundaries, unlike in other metallurgical states, which could explain the susceptibility to intergranular corrosion of the $\mathrm{T} 4+185^{\circ} \mathrm{C}-10 \mathrm{~h}$ samples. Therefore,

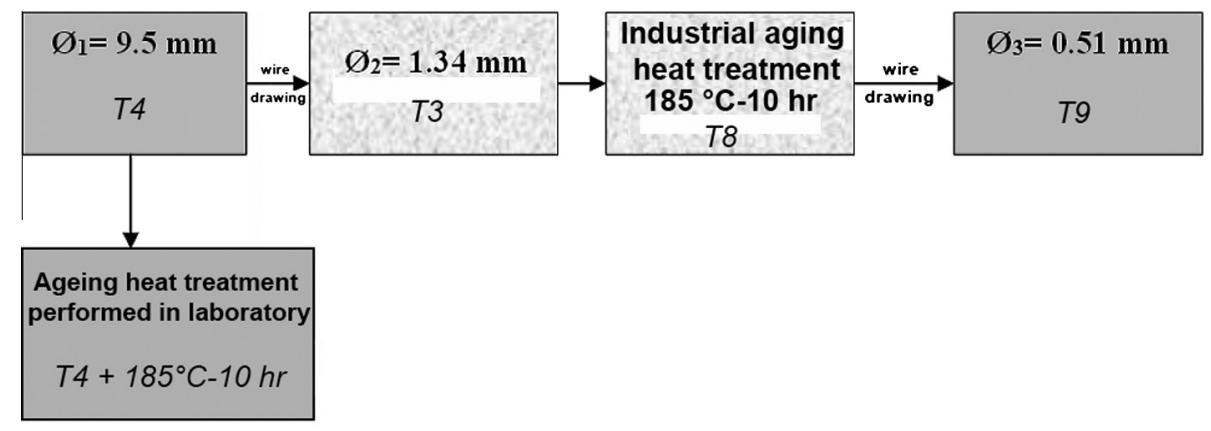

Fig. 1. Schematic presentation of the wire-drawing process used to manufacture the strand arms and resulting metallurgical states. 

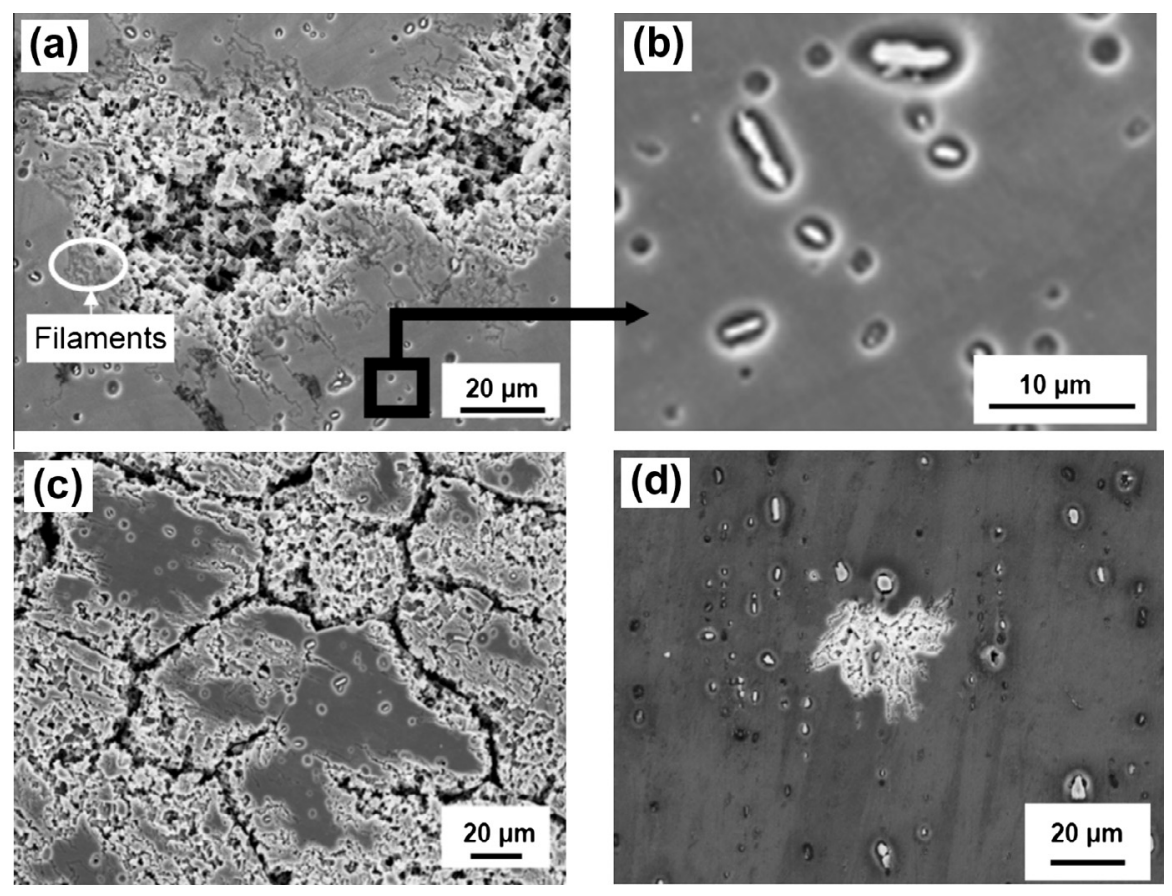

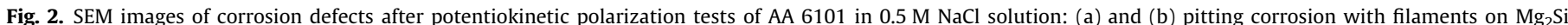

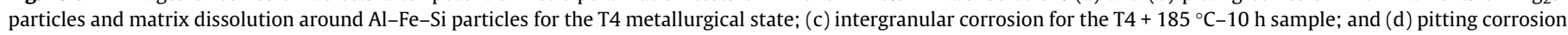
and matrix dissolution around particles for the T9 metallurgical state.

the results showed that the morphology of the corrosion defects depended on the metallurgical state of the 6101 aluminum alloy, suggesting different fatigue behavior after pre-corrosion damage or during fatigue-corrosion tests.

In this paper, the effect of pre-corrosion damage and fatiguecorrosion synergistic impact on fatigue life was studied for T4, $\mathrm{T} 4+185^{\circ} \mathrm{C}-10 \mathrm{~h}$, and $\mathrm{T} 9$ samples. Considerable effort was applied to the SEM analyses of the fracture surfaces resulting from the different tests for each metallurgical state; the observations were explained based on the microstructure and corrosion susceptibility of the different metallurgical states.

\section{Materials and methods}

\subsection{Material}

In the present work, AA 6101 in the T4 metallurgical state was provided by Rio Tinto Alcan as a wire rod with a $9.5 \mathrm{~mm}$ diameter. Its chemical composition is given in Table 1 . The T9 samples were prepared by SASA Trefil'Alu, whereas the $\mathrm{T} 4+185^{\circ} \mathrm{C}-10 \mathrm{~h}$ samples were prepared in the laboratory.

The microstructural characteristics of the initial wire rod and of the different metallurgical states obtained by the wire drawing process have been characterized in a previous work [22] by optical microscopy (OM), secondary electron microscopy (SEM), and transmission electron microscopy (TEM). A short description of these results is presented in the following subsections.

Table 1

Chemical composition (weight \%) of AA 6101 T4.

\begin{tabular}{lllllll}
\hline \multicolumn{7}{l}{ Element (wt. \%) } \\
\hline AA 6101 T4 & $\mathrm{Mg}$ & $\mathrm{Si}$ & $\mathrm{Fe}$ & $\mathrm{Cu}$ & $\mathrm{Mn}$ & $\mathrm{Al}$ \\
& 0.48 & 0.47 & 0.13 & 0.017 & 0.0021 & Bal. \\
\hline
\end{tabular}

\subsubsection{AA 6101 T4 metallurgical state}

OM observations performed under polarized light after anodic oxidation revealed an average grain size of $80-100 \mu \mathrm{m}$ in the transverse plane (perpendicular to the rod axis), $200 \mu \mathrm{m}$ in the longitudinal plane, and $130 \mu \mathrm{m}$ in the heart of the $9.5-\mathrm{mm}$-diameter wire rod. Globular shaped (average diameter of 3-4 $\mu \mathrm{m}$ ) or needle-shaped (average dimension $=4-5 \mu \mathrm{m} \times 1 \mu \mathrm{m}$ ) Al-Fe-Si particles were observed in the grains. As a result of the mechanical rolling, they were preferentially oriented in the direction of the plastic deformation. These particles were found to be responsible for pitting corrosion and matrix dissolution as mentioned above.

\subsubsection{AA $6101 \mathrm{~T} 4+185^{\circ} \mathrm{C}-10 \mathrm{~h}$ metallurgical state}

In comparison with the T4 metallurgical state, no difference was observed regarding the grain size or intragranular intermetallic particles. However, TEM observations showed that the aging treatment led to a fine intergranular precipitation, i.e., $\mathrm{Mg}_{2} \mathrm{Si}$ precipitates arranged as a continuous film, with needle or globular shapes, and the formation of a precipitate free zone (PFZ). In contrast, the T4 metallurgical state exhibited neither intergranular precipitates nor a PFZ, Moreover, needle-shaped hardening precipitates were observed in the matrix.

\subsubsection{AA 6101 T9 metallurgical state}

For this metallurgical state, TEM observations revealed intragranular precipitates identified as Al-Fe-Si particles but no intergranular precipitation [22]. It was impossible to directly determine the average grain size in the transverse plane owing to the very thin diameter of the wire $(0.51 \mathrm{~mm})$. Therefore, additional TEM observations were performed in the longitudinal direction. As described in the previous work [22], microstructural observations were conducted using a transmission electron microscope (JEOL-JEM-2010). The samples were obtained by cutting $280-\mu$ m-thick slices from the wire. The slices were ground to a thickness of approximately $100 \mu \mathrm{m}$, and a dimple was machined 
in the central region. Electron transparency was finally obtained by ion milling using a precision ion polishing system (PIPS ${ }^{\mathrm{TM}}$, Gatan) with $5 \mathrm{kV} \mathrm{Ar}{ }^{+}$ions. These observations revealed very elongated grains in the wire drawing direction whose length exceeded the observation surface but whose width $(500 \mathrm{~nm})$ reasonably corresponded to the average grain size in the transverse plane (Fig. 3(a) and (b)). Moreover, a high dislocation density was visible for this metallurgical state.

\subsection{Methods}

\subsubsection{Preliminary tensile tests}

Tensile tests were performed on the wire rods ( $9.5 \mathrm{~mm}$ thick, T4 and $\left.\mathrm{T} 4+185^{\circ} \mathrm{C}-10 \mathrm{~h}\right)$ and thin wires $(0.51 \mathrm{~mm}$ thick, T9 metallurgical state) using an MTS testing machine equipped with a $5 \mathrm{kN}$ load cell and at a constant strain rate of $10^{-3} \mathrm{~s}^{-1}$.

\subsubsection{Fatigue and fatigue-corrosion tests}

Stress-controlled uniaxial fatigue tests on pre-corroded samples were conducted at room temperature, in ambient air, on a precision-aligned fatigue machine (BOSE ElectroForce $3330^{\circledR}$ ), providing static to $100 \mathrm{~Hz}$ performance with a load envelope of $\pm 3300 \mathrm{~N}$. Tests were also performed on non-corroded samples for comparison. For the $\mathrm{T} 4$ and $\mathrm{T} 4+185^{\circ} \mathrm{C}-10 \mathrm{~h}$ metallurgical states, the fatigue sample shape was cylindrical (3.5 mm of diameter $\times 20 \mathrm{~mm}$ of length), as shown in Fig. 4. For AA 6101 T9 samples, fatigue tests were conducted directly on thin wires $(0.51 \mathrm{~mm}$ of diameter $\times 137 \mathrm{~mm}$ of length) using specific grips. The sample sizes were chosen in order to have the same specimen area exposed to the corrosive media for each geometry, i.e., an area equal to $220 \mathrm{~mm}^{2}$. Also, crack initiation step was mainly influenced by the size of initiating defects compared to the diameter of specimens and not by a probability to find more or less initiating features on the exposed surfaces.

For the $\mathrm{T} 4$ and $\mathrm{T} 4+185^{\circ} \mathrm{C}-10 \mathrm{~h}$ metallurgical states, the sample surface was prepared by electrolytic polishing, avoiding residual surface stresses and leading to a roughness of $1 \mu \mathrm{m}$. For the T9 samples, no surface preparation was performed. Before fatigue tests, some samples were pre-corroded, which consisted of $72 \mathrm{~h}$ of continuous immersion in a $0.5 \mathrm{NaCl}$ aerated solution.

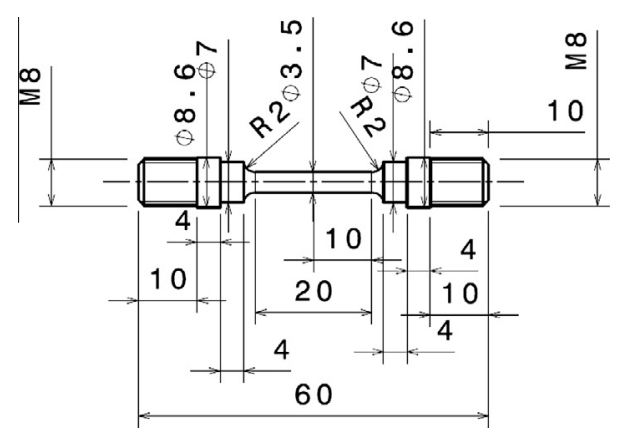

Fig. 4. Geometry of cylindrical fatigue samples of AA $6101 \mathrm{~T} 4$ and $\mathrm{T} 4+185^{\circ} \mathrm{C}-10 \mathrm{~h}$.

Concerning fatigue-corrosion tests, a specific test bench was designed. This bench was composed of a leak-tight corrosion cell adapted to the fatigue machine, in which the corrosive solution was continuously circulated by a peristaltic pump. A Julabo ${ }^{\circledR}$ refrigerated/heating circulator was used to control the temperature $\left(25^{\circ} \mathrm{C}\right)$ of the electrolyte $(0.5 \mathrm{M} \mathrm{NaCl}$ solution $)$ in the corrosion cell via an external Pyrex ${ }^{\circledR}$ thermal exchanger.

Fatigue life and fatigue-corrosion life tests were carried out using a $50 \mathrm{~Hz}$ sine wave with a stress ratio of $R=0.1$ (with $R=\sigma_{\mathrm{min}} /$ $\left.\sigma_{\max }\right)$. The results of these tests are presented as a plot of stress level $(\sigma)$ as a function of the number of cycles to failure $(N)(S-N$ curves). Three stress levels were considered: $95 \%, 89 \%$, and $82 \%$ of the ultimate tensile strength (UTS) preliminarily determined for each metallurgical state in air. These stress levels are representative of operating conditions. Assumed that this alloy presents an isotropic strain hardening behavior, plasticity principally occurs during the first part of the first cycle for this stress ratio level. Then, when the corrosion defects appear, there is a local stress amplification leading to a possible cyclic plasticity.

\subsubsection{Scanning electron microscope (SEM) observations}

Scanning electron microscopy (LEO-435-VP) was performed with an incident electron beam between $10 \mathrm{kV}$ and $15 \mathrm{kV}$ to carefully examine the corrosion defects and the fracture surface obtained after tensile and fatigue and/or fatigue-corrosion tests.
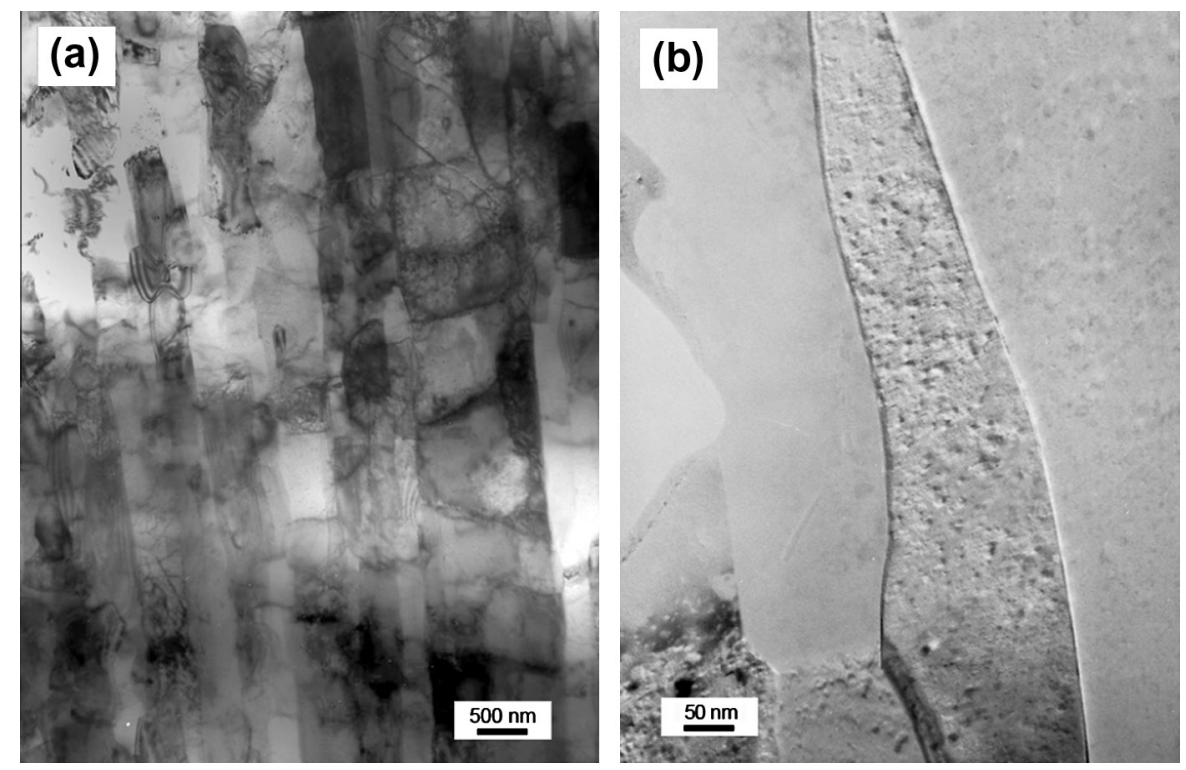

Fig. 3. TEM images of AA 6101 T9: (a) general view and (b) local view of grain boundaries. 


\section{Results and discussion}

3.1. Preliminary characterization of the tensile behavior and fatigue endurance of $A A 6101$ in the $\mathrm{T} 4, \mathrm{~T} 4+185^{\circ} \mathrm{C}-10 \mathrm{~h}$ and $\mathrm{T9}$ metallurgical states

\subsubsection{Tensile behavior}

The tensile curves obtained for the three metallurgical states are presented in Fig. 5. The T9 metallurgical state presented a strong increase in the yield strength and ultimate tensile strength combined with a very low plastic deformation. This behavior corresponded well with a Hall-Petch strengthening effect related to the very fine grain size due to the wire-drawing process and the high dislocation density observed by TEM.

Concerning the $\mathrm{T} 4$ and $\mathrm{T} 4+185^{\circ} \mathrm{C}-10 \mathrm{~h}$ metallurgical states, the heat treatment increased the tensile mechanical properties but decreased the strain to failure. The T9 metallurgical state has the highest yield strength and the weakest strain to failure. This result could be related to the precipitation of strengthening precipitates following the heat treatment at $185^{\circ} \mathrm{C}$, which is consistent with the literature on 6xxx aluminum alloys [33,34].

The tensile fracture surfaces obtained for each metallurgical state are presented in Fig. 6. For AA 6101 T4 and T9, the same failure mode was observed, i.e., ductile failure by nucleation on $\mathrm{Al}-\mathrm{Fe}-$ Si particles and the growth and coalescence of dimples (Fig. 6(a) and (b)). For the $\mathrm{T} 4+185^{\circ} \mathrm{C}-10 \mathrm{~h}$ metallurgical state, a mixed failure mode with a transgranular ductile fracture associated with intergranular ductile fracture was observed, (Fig. 6(c)). A higherresolution image of these intergranular interfaces showed that they were covered by dimples that were smaller than those observed in the transgranular ductile fracture zone (Fig. 6(d)). The nucleation of the dimples localized on intergranular interfaces could be explained by the $\mathrm{Mg}_{2} \mathrm{Si}$ intergranular precipitates homogeneously distributed as previously observed by TEM for the $\mathrm{T} 4+150^{\circ} \mathrm{C}-10 \mathrm{~h}$ metallurgical state [22]. The intergranular rupture was due to a ductile intergranular rupture mechanism promoted by the precipitation of intergranular phases during the heat treatment and likely also by the presence of a PFZ close to the grain boundaries that tended to localize the deformation.

\subsubsection{Fatigue endurance behavior}

Fatigue life curves are presented in Fig. 7 for each metallurgical state. The stress level was calculated by comparison to the ultimate tensile strength of the sample to take into account the evolution of the mechanical properties during the metalworking process and

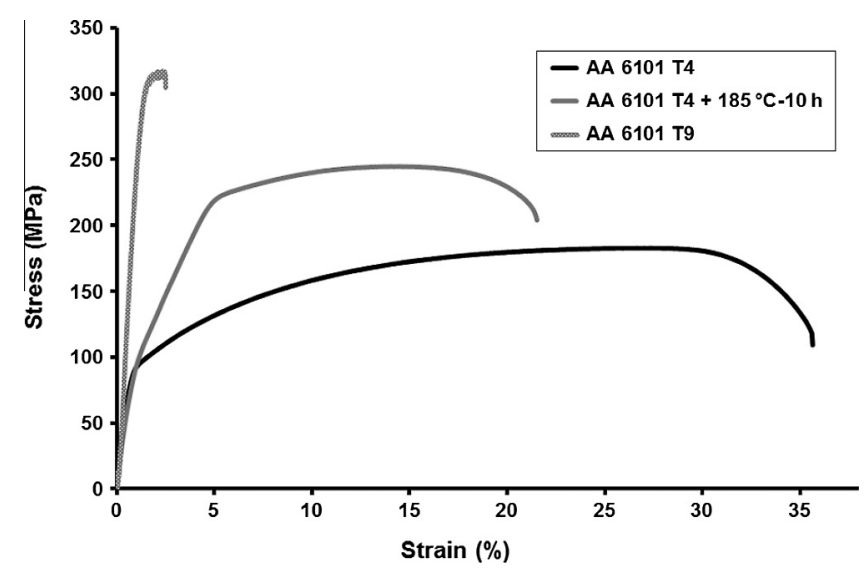

Fig. 5. Tensile curves of $\mathrm{AA} 6101 \mathrm{~T} 4, \mathrm{~T} 4+185^{\circ} \mathrm{C}-10 \mathrm{~h}$, and $\mathrm{T} 9$ at $25^{\circ} \mathrm{C}$ (strain rate: $\left.10^{-3} \mathrm{~s}^{-1}\right)$. finally to compare metallurgical states to each other. The choice of this normalization is based on a parallel with literature results on steels which have shown a correlation, though still very approximate, between fatigue limit and UTS even if, in our case, it is known that aluminum alloys do not show a distinct fatigue limit $[35,36]$. Finally this tensile strength is probably the most easy and relevant parameter to compare the different metallurgical states in a first approach. Another hypothesis was considered in this work, that initiating defects distribution on surface samples was the same for all the metallurgical states. In this work, the fatigue crack initiation was principally dependent on the mechanical solicitation (coupled or not with the corrosive media effect) and the microstructure but remained independent of defect distribution on the sample surface.

The $185^{\circ} \mathrm{C}-10 \mathrm{~h}$ heat treatment led to a strong decrease in the fatigue life while T9 metallurgical state seemed to present the best fatigue endurance behavior.

To gain a better understanding of the failure modes occurring during fatigue life tests, the fracture surfaces were observed by SEM. Fig. 8 presents the micrographs obtained for the T4 metallurgical state. Following the crack initiation on surface sample, a first zone was observed, showing a transgranular rupture mode characterized by smooth crystallographic facets (Fig. 8(b)). This type of rupture mode has already been observed by other authors [3739] for aluminum alloys and was assimilated to $\{111\}$ surface facets. This slow crack propagation stage at a microstructure scale can be explained by a preferential localization of the plastic deformation within a single persistent slip band.

Some ductile zones were observed between the facets, corresponding to the rupture of ligaments localized between the crystallographic rupture zones. The transition between the crystallographic propagation zone and the finale ductile rupture presented a mixed rupture mode, i.e., ductile and crystallographic, where no striation or river marks were observed (Fig. 8(c)). The final rupture exhibited a ductile failure mode (Fig. 8(d)).

Fig. 9 presents the micrographs obtained for the $\mathrm{T} 4+185^{\circ} \mathrm{C}-$ $10 \mathrm{~h}$ metallurgical state. The initiation zone was characterized by an intergranular fracture mode (Fig. 9(a), (b), and (c)). Indeed, measurements performed on the intergranular surfaces (Fig. 9(c)) observed by SEM led to a grain size in good agreement with the average grain size measured using $\mathrm{OM}$ in the transverse direction. Therefore, the heat treatment led to a new type of fracture mode relative to the T4 metallurgical state, i.e., an intergranular rupture mode, probably due to the appearance of a precipitate-free zone (PFZ) combined with the precipitation of $\mathrm{Mg}_{2} \mathrm{Si}$ intergranular precipitates [22]. The PFZ could be seen as a soft zone wrapping the grains which favors the intergranular crack initiation by cyclic plasticity accumulation along grain boundaries. This effect could be potentially reinforced by cavities nucleation and growth on $\mathrm{Mg}_{2} \mathrm{Si}$ intergranular precipitates present on favorably oriented grain boundaries [40,41].

Finally, the intergranular cracks then may have formed a main crack that propagated according to the characteristic marks of propagation, i.e., fatigue striations or river marks, as observed in Fig. 9(d). The premature initiation stage combined with the propagation step was most likely responsible for the strong decrease in the fatigue endurance of the alloy. The final rupture was characterized by a ductile rupture via homogeneous dimple coalescence.

Concerning the T9 metallurgical state, Fig. 10 presents the SEM micrographs of the fracture surfaces obtained after the fatigue endurance test. The global view reveals two different zones related to the slow crack propagation regime and the ductile final rupture (Fig. 10(a)). The slow crack propagation zone presented very small rupture interfaces, which suggested an intergranular rupture at a nanoscale related to the small size of the grains (Fig. 10(b) and (c)), even if a slight transgranular zone might exist. 

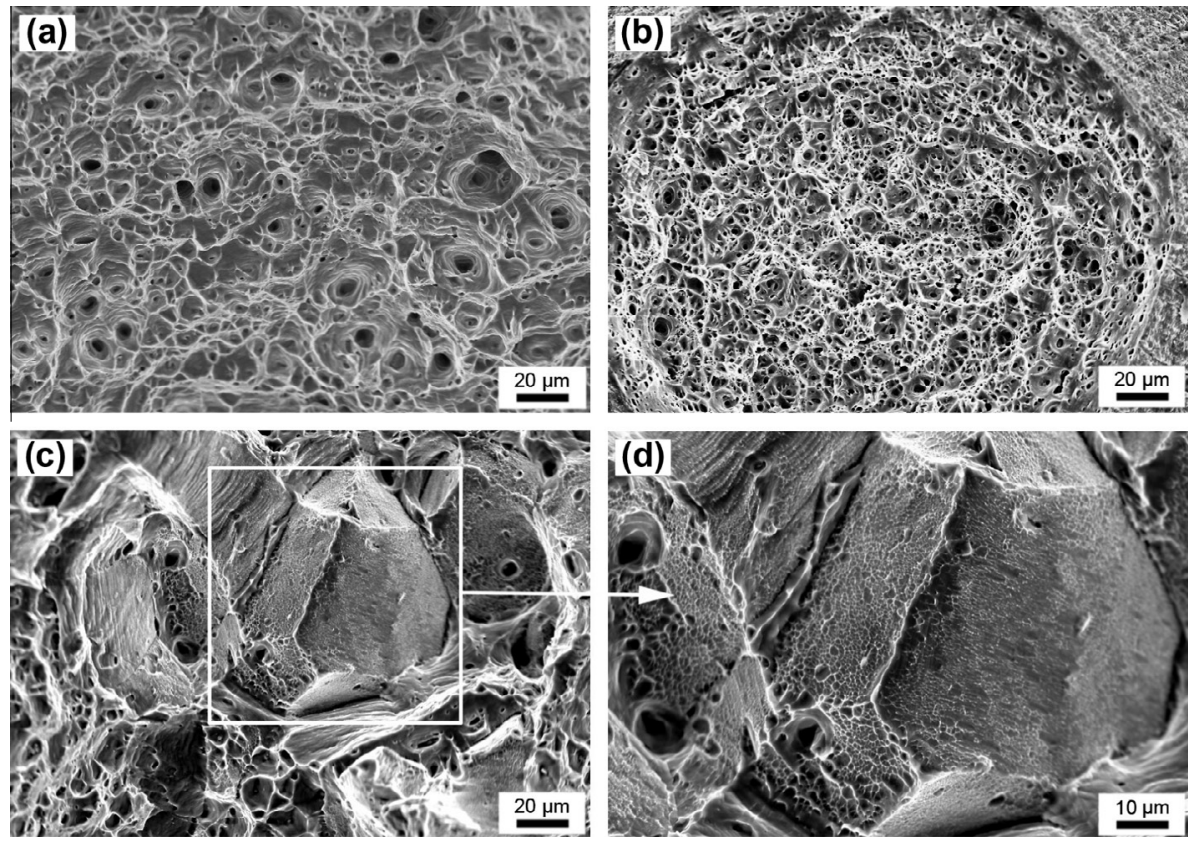

Fig. 6. SEM images of tensile fracture surfaces of AA 6101 (a) T4, (b) T9, and (c) and (d) T4 + $185^{\circ} \mathrm{C}-10 \mathrm{~h}$.

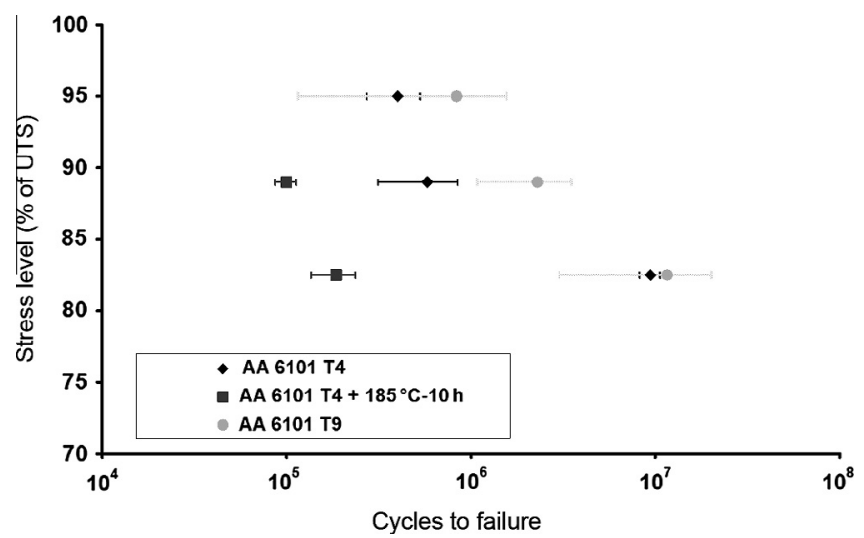

Fig. 7. Fatigue life curves of $\mathrm{AA} 6101 \mathrm{~T} 4, \mathrm{~T} 9$, and $\mathrm{T} 4+185^{\circ} \mathrm{C}-10 \mathrm{~h}(R=0.1, f=50 \mathrm{~Hz}$, $T=25{ }^{\circ} \mathrm{C}$ ) for three stress levels: $95 \%, 89 \%$, and $82 \%$ of the ultimate tensile strength.

To confirm this hypothesis, AA 6101 T9 was subjected to liquid metal embrittlement by means of gallium. Indeed, exposure to gallium allow the granular structure of aluminum alloys to be observed because these materials are particularly sensitive to intergranular decohesion due to gallium penetration and diffusion along grain boundaries. The resulting rupture surface is presented in Fig. 11. This figure showed an intergranular rupture very similar to the fracture surface obtained after fatigue endurance tests on the T9 metallurgical state (Fig. 10(c)) that confirmed crack propagation by an intergranular rupture mechanism.

The slow crack propagation stage was followed by the ductile final rupture via the coalescence of dimples. The effect of the reduction of grain size on fatigue endurance was widely studied in the literature [42-44]. It was observed by certain authors that when the grain size decreased, the numerous grain boundaries acted as microstructural barriers or a restraint of dislocation movement and finally delayed crack initiation.

However, other authors have observed that decreasing the grain size could lead to increase propagation rates and decrease the threshold stress intensity factor [45]. Höpple et al. have shown that the grain size, ranging from the micrometer to the nanometer range significantly affects the very high cycle fatigue (VHCF) behavior of two aluminum alloys [46]. For AA1050 with a grain size $55 \mu \mathrm{m}$ no late failure was obtained, whereas for the same material with an ultrafine grain size of $600 \mathrm{~nm}$ a stepwise SN-curve was found. In the case of the precipitation hardened material AA6082 they found that the local mechanical properties of the matrix significantly governs the crack initiation step and hence the VHCF-behavior. In this study, the grain size is probably not the only parameter to consider. It could be interesting to determine more precisely the characteristics of grain boundaries and plasticity mechanisms for this nanoscale microstructure issued from the wire drawing process such as boundary disorientation, stackingfault energy, active secondary sliding systems [47].

\subsection{Effect of pre-corrosion on fatigue life}

To better understand fatigue-corrosion interactions, it was necessary to characterize the effect of pre-corrosion damage on fatigue life and fracture modes.

The fatigue life curves plotted after the pre-corrosion treatment are presented in Fig. 12 for each metallurgical state. Table 2 summarizes the results obtained for the pre-corroded samples and non-corroded samples; the ratios $\mathrm{Nf}_{\mathrm{pc}} / \mathrm{Nf}_{\mathrm{nc}}$, where $\mathrm{Nf}_{\mathrm{pc}}$ is the lifetime for a pre-corroded sample and $\mathrm{Nf}_{\mathrm{nc}}$ is the lifetime for a noncorroded sample, are given for each metallurgical state and stress level. The results showed a slight decrease in fatigue endurance for the $\mathrm{T} 4$ and $\mathrm{T} 4+185^{\circ} \mathrm{C}-10 \mathrm{~h}$ metallurgical states due to the pre-corrosion treatment but a strong decrease in the fatigue life for the T9 metallurgical state. These points will be discussed in more detail later in this paper.

Failure modes occurring during fatigue life tests on pre-corroded samples were characterized by SEM observations. For all metallurgical states, the crack initiation was localized on a corrosion defect. Fig. 13 presents the micrographs obtained for the T4 metallurgical state. The crack initiation was localized on a corrosion defect, i.e., a 20- $\mu$ m-diameter pit (Fig. 13(b)), and the corrosion morphology observed was in good agreement with the 

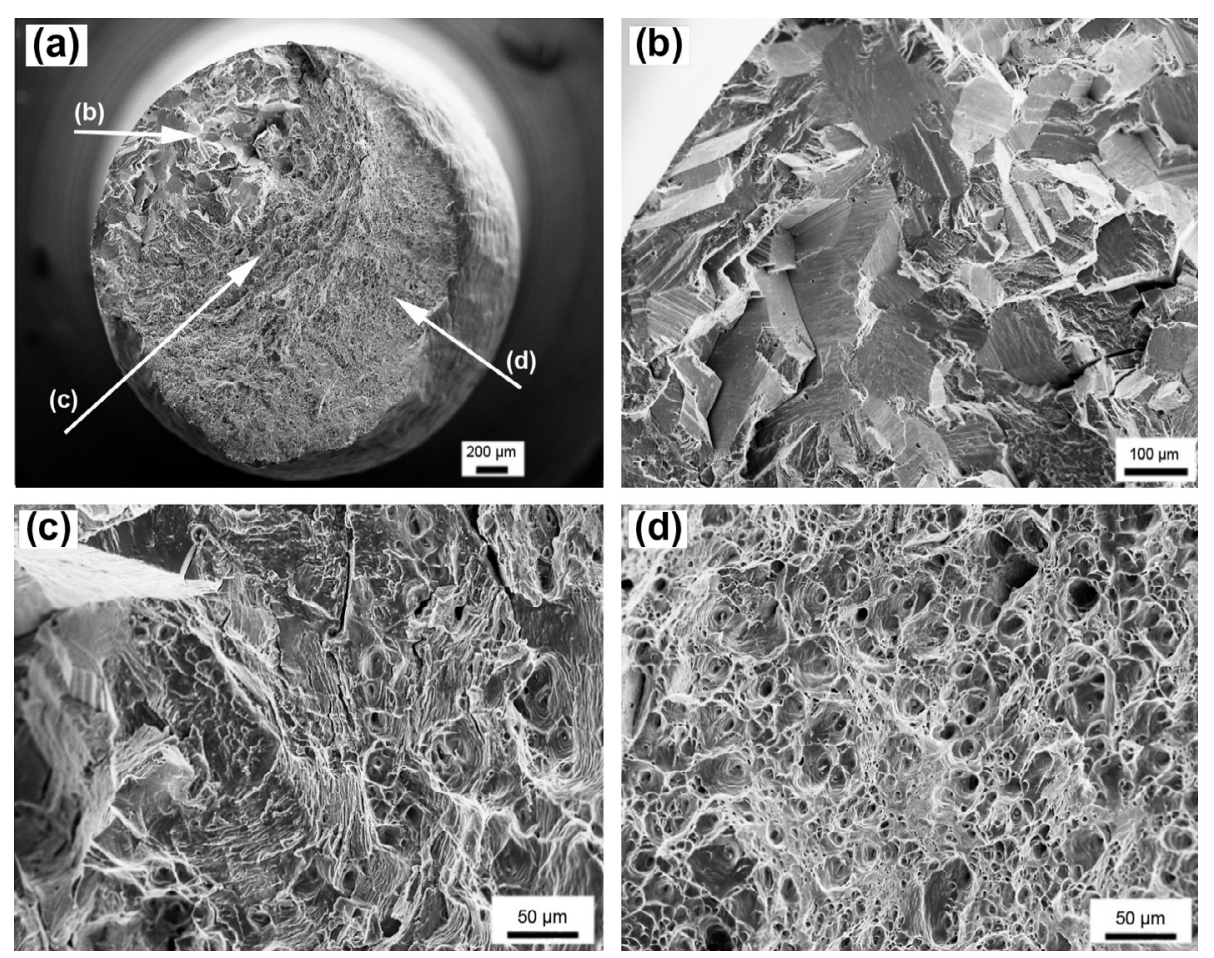

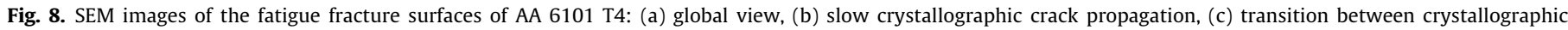
propagation and ductile rupture, and (d) final rupture (for $\sigma=89 \%$ of the ultimate tensile strength).
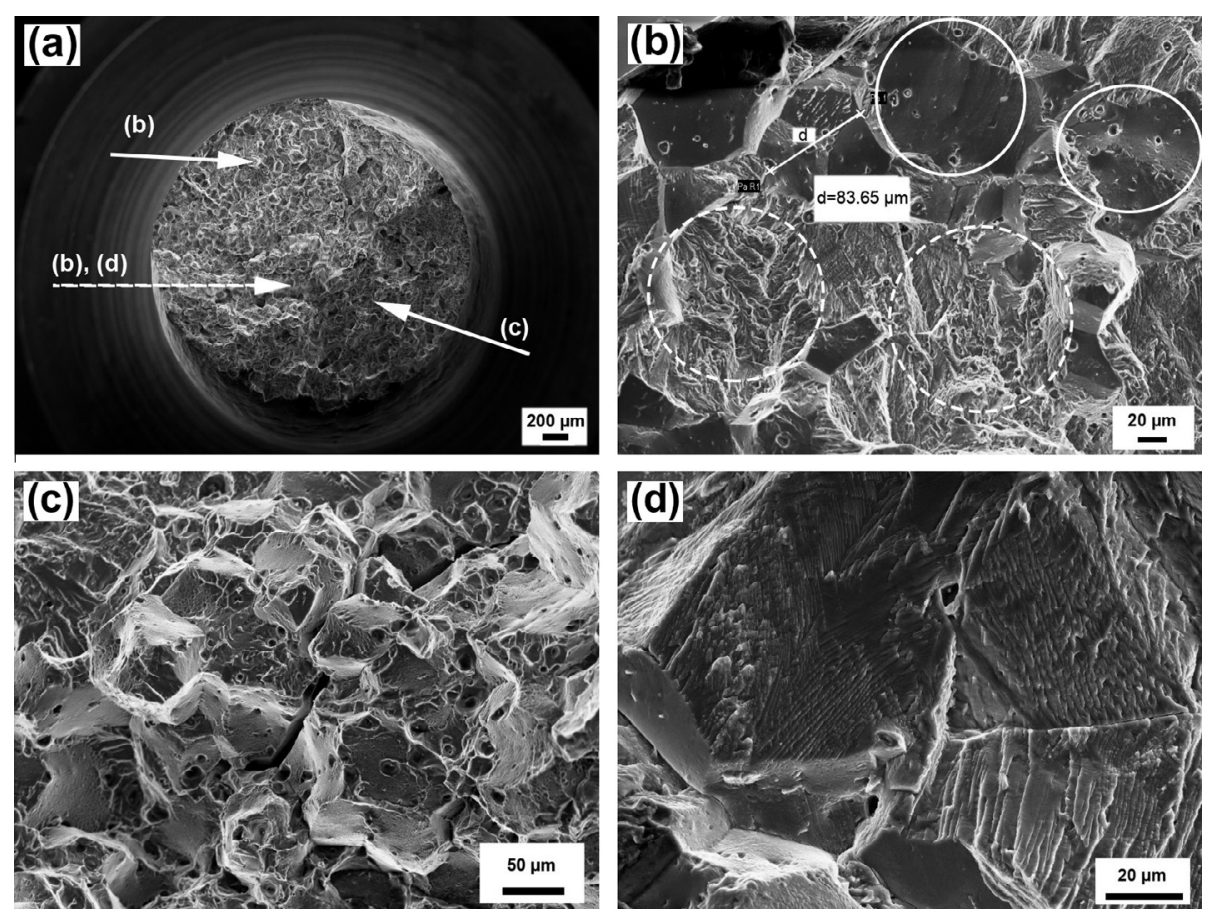

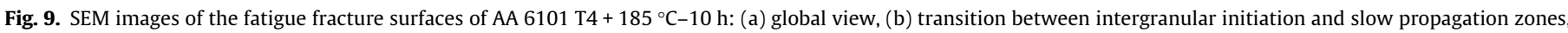
(c) zoomed image of the intergranular initiation zone, and (d) zoomed image of the slow propagation zone (for $\sigma=89 \%$ of ultimate tensile strength).

results presented in a previous work [22]. The pre-corrosion treatment did not change the nature of the rupture mode for the slow crack propagation stage, which remained transgranular with crystallographic facets. The ratio between the area of the slow crack propagation stage, i.e., crystallographic features, and the area of the global fracture surface is equal to $25 \%$. The same ratio was found for the fatigue tests performed on T4 metallurgical state in air without pre-corrosion damage that suggested that this step was rather logically not influenced by the pre-corrosion damage. More generally, even if the crack initiation was localized on a corrosion defect, the initiation stage was not reduced, considering the slight decrease in fatigue endurance. 

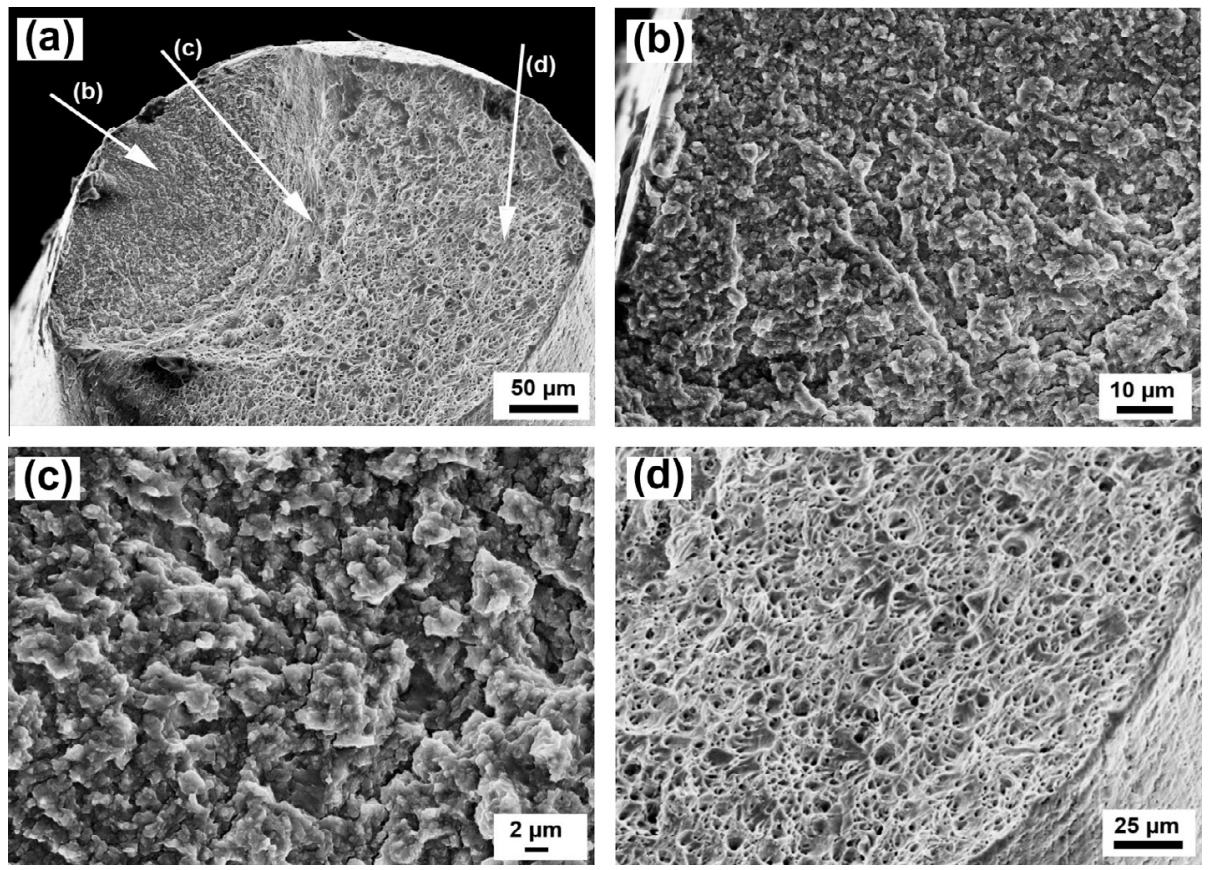

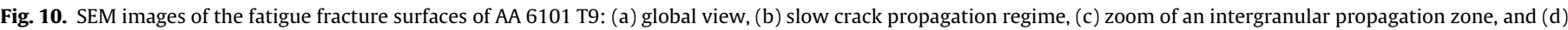
final ductile rupture (for $\sigma=89 \%$ of ultimate tensile strength).

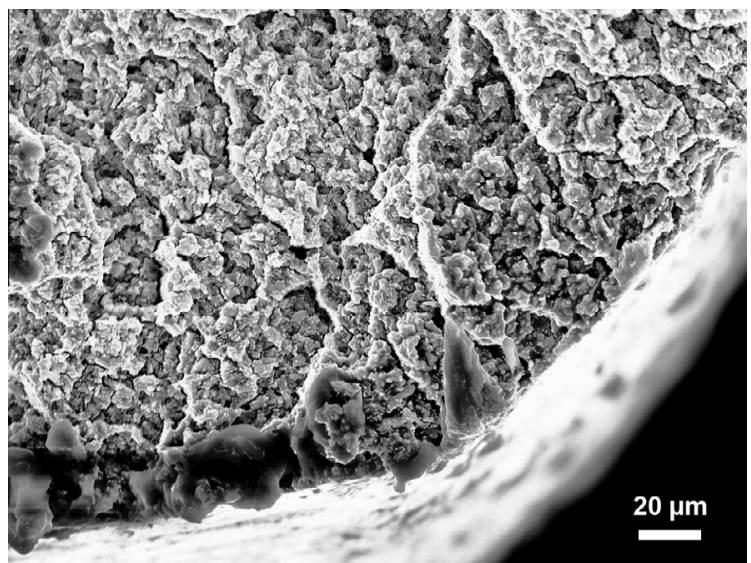

Fig. 11. SEM image of the fatigue fracture surface of AA 6101 T9 after liquid meta embrittlement by means of gallium.

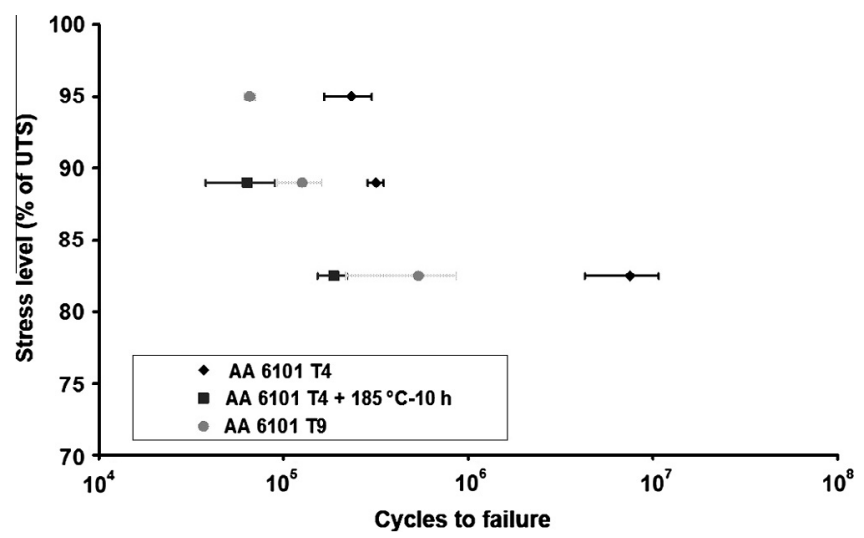

Fig. 12. Fatigue life curves for pre-corroded samples of AA $6101 \mathrm{~T} 4$, T9, and $\mathrm{T} 4+185^{\circ} \mathrm{C}-10 \mathrm{~h}\left(R=0.1, f=50 \mathrm{~Hz}, T=25^{\circ} \mathrm{C}\right)$ for three stress levels: $95 \%, 89 \%$, and $82 \%$ of the ultimate tensile strength.
Concerning the $\mathrm{T} 4+185^{\circ} \mathrm{C}-10 \mathrm{~h}$ metallurgical state, the same conclusions could be drawn. The crack initiation was localized on a corrosion defect, i.e., an intergranular corrosion defect (Fig. 14(b)) according to previous corrosion tests [22]. Once the crack initiated on the intergranular corrosion defect, it propagated until the final rupture. The different morphologies observed, i.e., rivers and striations, likely just reflect local $\Delta K$ dependent cracking mechanisms. Of course, local chemical evolution due to corrosion processes, i.e., hydrogen enrichment, could also be taken into account. Indeed, during the pre-corrosion treatment, the increased reactivity of the grain boundaries due to the presence of intergranular precipitates could be associated with an acidification of the electrolyte trapped inside the grain boundaries followed by protons reduction and eventually a hydrogen-uptake. Hydrogen could be assumed to affect the local mechanical properties.

The T9 metallurgical state was clearly the most affected by the pre-corrosion treatment. The fatigue crack initiated on a pit of $20 \mu \mathrm{m}$ of diameter. As a reminder, the T4 metallurgical state presented the same type and size of localized corrosion than the T9 metallurgical state but its fatigue endurance was not as decreased as T9 metallurgical state (Fig. 12). Given that the specimen areas exposed to corrosive media are similar for the two sample geometries, the strong decrease of the fatigue endurance of the T9 metallurgical state was most likely due to the ratio between the size of the corrosion defects generated during the pre-corrosion treatment and the wire diameter. Indeed, the ratio $a / w$ (with $a$ : the size of the pit and $w$ : the diameter of the wire or the cylindrical specimen) is 20 times higher for T9 than for T4 metallurgical state that favors the initiation crack. Finally, the beneficial effect of the small grain size on crack initiation is lost owing to the presence of a corrosion defect whose size is not negligible compared to the diameter of the wire.

The propagation rupture modes were similar to those observed for non-pre-corroded samples, with a rupture mode essentially intergranular followed by a ductile final rupture (Fig. 15). 
Table 2

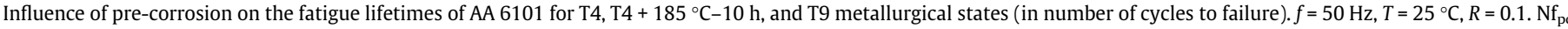
is the lifetime for a pre-corroded sample and $\mathrm{Nf}_{\mathrm{nc}}$ the lifetime for a non-corroded sample.

\begin{tabular}{|c|c|c|c|}
\hline & Non-corroded samples & Pre-corroded samples & $\mathrm{Nf}_{\mathrm{pc}} / \mathrm{Nf}_{\mathrm{nc}}$ ratios \\
\hline $\begin{array}{l}\text { T4 } \\
\sigma=95 \% \text { of UTS } \\
\sigma=89 \% \text { of UTS } \\
\sigma=82.5 \% \text { of } U T S\end{array}$ & $\begin{aligned} 400 & \times 10^{3} \pm 130 \times 10^{3} \\
580 & \times 10^{3} \pm 265 \times 10^{3} \\
9407 & \times 10^{3} \pm 1185 \times 10^{3}\end{aligned}$ & $\begin{array}{c}233 \times 10^{3} \pm 67 \times 10^{3} \\
317 \times 10^{3} \pm 31 \times 10^{3} \\
7513 \times 10^{3} \pm 3238 \times 10^{3}\end{array}$ & $\begin{array}{l}0 \times 7 \pm 0 \times 3 \\
0 \times 7 \pm 0 \times 3 \\
0.8 \pm 0.2\end{array}$ \\
\hline $\begin{array}{l}T 4+185^{\circ} \mathrm{C}-10 \mathrm{~h} \\
\sigma=95 \% \text { of } U T S \\
\sigma=89 \% \text { of UTS } \\
\sigma=82.5 \% \text { of UTS }\end{array}$ & $\begin{array}{c}- \\
100 \times 10^{3} \pm 13 \times 10^{3} \\
186 \times 10^{3} \pm 50 \times 10^{3}\end{array}$ & $\begin{array}{c}- \\
64 \times 10^{3} \pm 26 \times 10^{3} \\
187 \times 10^{3} \pm 34 \times 10^{3}\end{array}$ & $\begin{array}{c}- \\
0.66 \pm 0.33 \\
0.8 \pm 0.2\end{array}$ \\
\hline $\begin{array}{l}\text { T9 } \\
\sigma=95 \% \text { of UTS } \\
\sigma=89 \% \text { of UTS } \\
\sigma=82.5 \% \text { of UTS }\end{array}$ & $\begin{aligned} 836 & \times 10^{3} \pm 721 \times 10^{3} \\
2295 & \times 10^{3} \pm 1216 \times 10^{3} \\
11588 & \times 10^{3} \pm 8572 \times 10^{3}\end{aligned}$ & $\begin{array}{c}65 \times 10^{3} \pm 4 \times 10^{3} \\
126 \times 10^{3} \pm 34 \times 10^{3} \\
538 \times 10^{3} \pm 319 \times 10^{3}\end{array}$ & $\begin{array}{l}0.32 \pm 0.3 \\
0.08 \pm 0.06 \\
0.14 \pm 0.06\end{array}$ \\
\hline
\end{tabular}
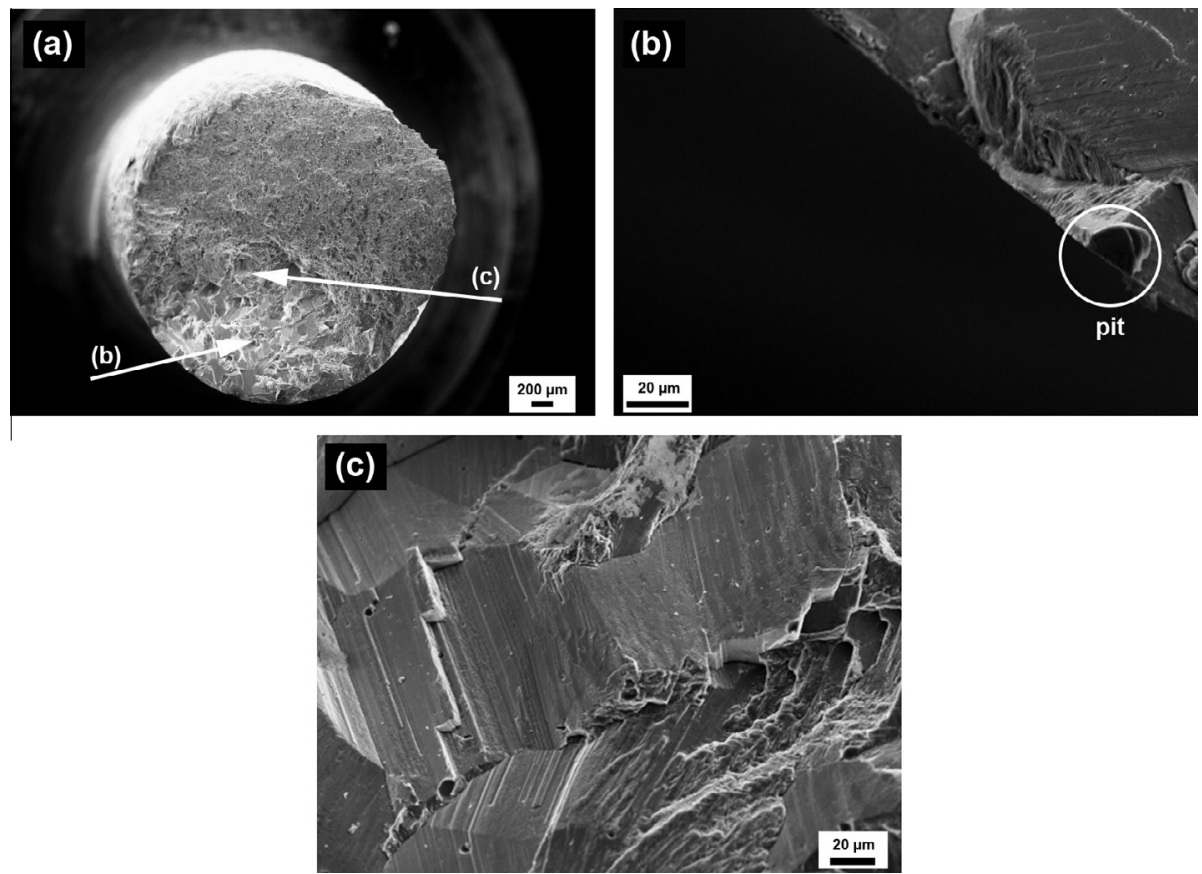

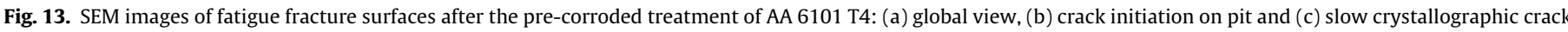
propagation ( $\sigma=89 \%$ of the ultimate tensile strength).

\subsection{Fatigue-corrosion tests}

The results of fatigue life tests performed in corrosive media, i.e., a $0.5 \mathrm{M} \mathrm{NaCl}$ solution, at $25^{\circ} \mathrm{C}$ are presented in Fig. 16 for each metallurgical state. Table 3 summarizes the results obtained from the fatigue-corrosion tests for each metallurgical test and stress level; the results obtained for non-corroded samples are also given. Moreover, the ratios $\mathrm{Nf}_{\mathrm{fc}} / \mathrm{Nf}_{\mathrm{nc}}$, where $\mathrm{Nf}_{\mathrm{fc}}$ is the lifetime for a sample submitted to a fatigue-corrosion test and $\mathrm{Nf}_{\mathrm{nc}}$ is the lifetime for a non-corroded sample, are given. The $\mathrm{Nf}_{\mathrm{pc}} / \mathrm{Nf}_{\mathrm{nc}}$ ratios are reported for comparison. For the $\mathrm{T} 4$ and $\mathrm{T} 4+185^{\circ} \mathrm{C}-10 \mathrm{~h}$ metallurgical states, the decrease in the fatigue lifetime measured during a fatigue-corrosion test compared to the fatigue lifetime measured in air $\left(\mathrm{Nf}_{\mathrm{fc}} / \mathrm{Nf}_{\mathrm{nc}}\right)$ was higher than the decrease observed due to the pre-corrosion treatment $\left(\mathrm{Nf}_{\mathrm{pc}} / \mathrm{Nf}_{\mathrm{nc}}\right)$. This result suggested a synergistic effect between fatigue and corrosion for the two metallurgical states only if the fatigue crack initiation occurred on a similar corrosion defect between fatigue-corrosion test and fatigue life tests on pre-corroded samples. This point was confirmed by SEM observations of fracture surfaces. The fatigue contribution during fatigue-corrosion tests did not change or enhance the corrosion damage responsible for the crack initiation. Taking into account the duration of the fatigue-corrosion tests $(1.5 \mathrm{~h}$ for $\sigma=95 \%$ of UTS, 2 h for $\sigma=89 \%$ of UTS and $4 \mathrm{~h} \sigma=82 \%$ of UTS for the T4 samples), which corresponded to the duration of exposure to the aggressive solutions compared to the immersion time $(72 \mathrm{~h})$ in $0.5 \mathrm{M} \mathrm{NaCl}$ for the pre-corrosion treatment, this synergistic effect appeared to be very strong. In contrast, for the T9 metallurgical state, this effect was not observed. This result will be discussed later in this paper.

Fig. 17 presents the SEM images of the fracture surfaces obtained after fatigue-corrosion endurance tests on AA $6101 \mathrm{~T} 4$. Analogously to fatigue tests performed on pre-corroded samples, crack initiation was localized on a corrosion pit whose size was similar to the size of the pit observed on pre-corroded sample. The main difference between fatigue-corrosion tests and fatigue life tests on pre-corroded samples was the appearance of an intergranular rupture mode combined with the crystallographic propagation (Fig 17(a) and (b)). The dimensions of the intergranular surfaces were well correlated with the average grain size (line $d$ 

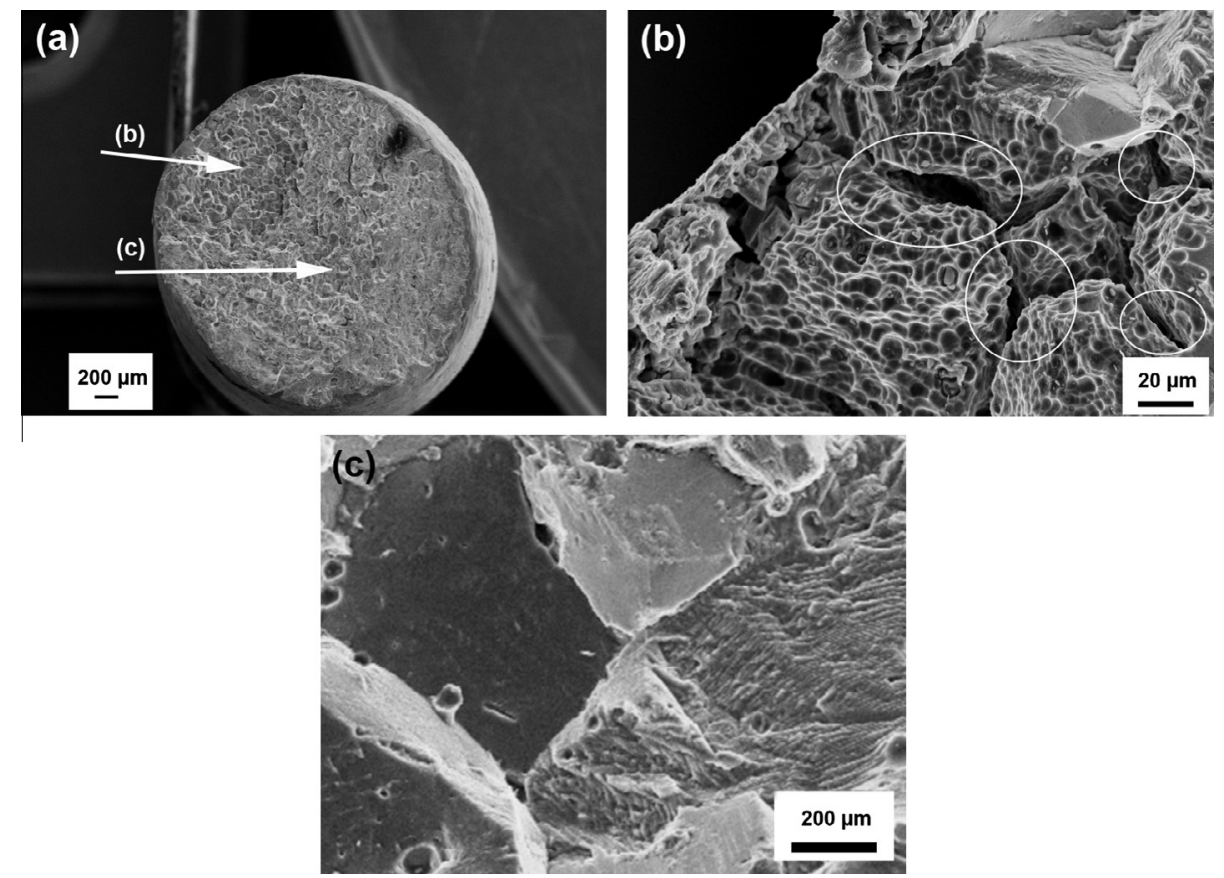

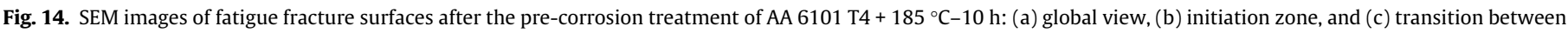
intergranular initiation (grain boundaries are surrounded in white) and slow propagation zone (for $\sigma=89 \%$ of the ultimate tensile strength).
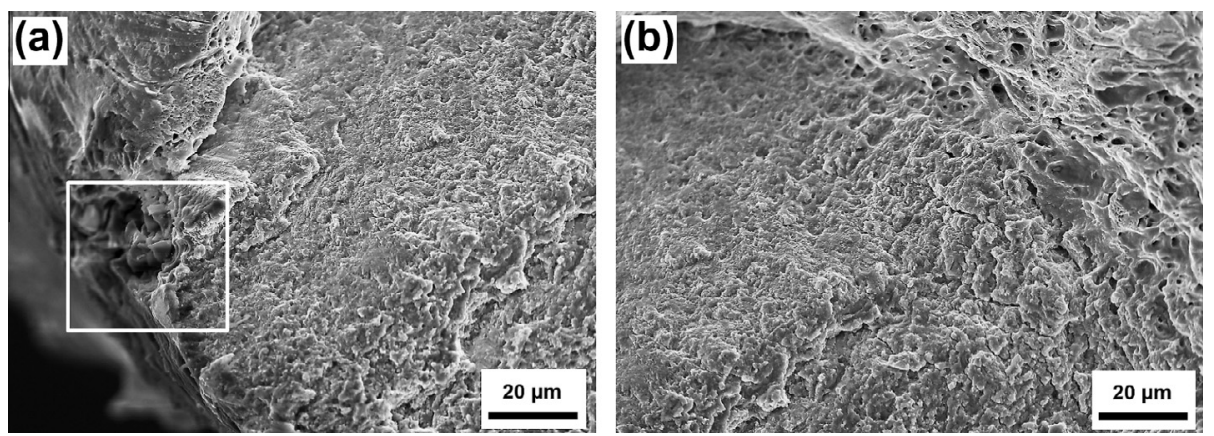

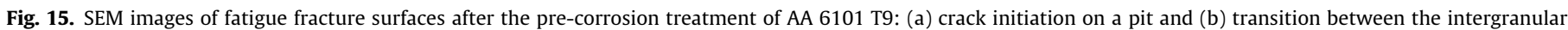
propagation zone and the ductile final rupture ( $\sigma=89 \%$ of the ultimate tensile strength).

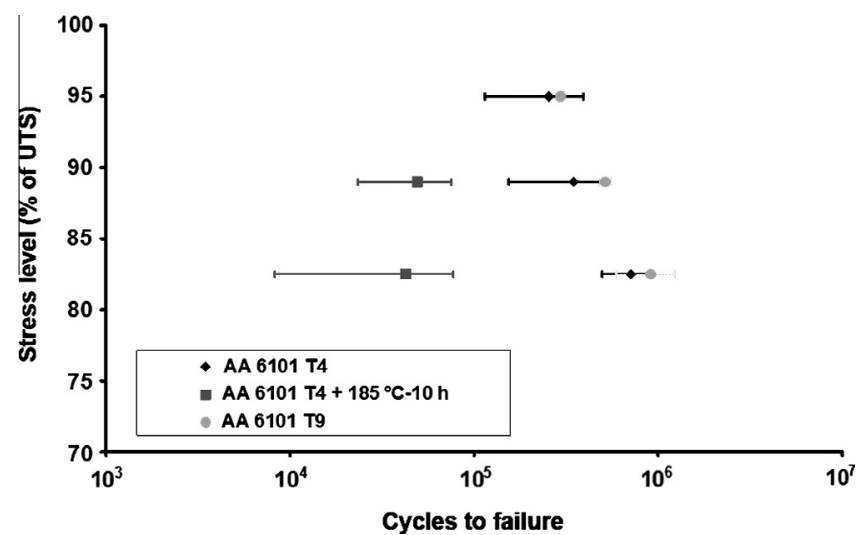

Fig. 16. Fatigue-corrosion life curves of $\mathrm{AA} 6101 \mathrm{~T} 4$, $\mathrm{T} 9$, and $\mathrm{T} 4+185^{\circ} \mathrm{C}-10 \mathrm{~h}$ $\left(R=0.1, f=50 \mathrm{~Hz}, T=25^{\circ} \mathrm{C}\right)$ for three stress levels: $95 \%, 89 \%$, and $82 \%$ of the ultimate tensile strength.

in Fig. 17(c)). The final rupture remained ductile with the coalescence of dimples. The synergistic effect between fatigue and corrosion previously mentioned seems to have an effect only on the slow crack propagation with the appearance of an intergranular rupture mode and not on the crack initiation.

For the $\mathrm{T} 4+185^{\circ} \mathrm{C}-10 \mathrm{~h}$ metallurgical state, the SEM images of the fracture surfaces are presented in Fig. 18. Such as for T4 metallurgical state, the crack initiation occurred on corrosion defect similar to the corrosion defect generated by pre-corrosion. The same fracture modes were observed as in the fatigue tests performed on the healthy and pre-corroded samples. However, the proportion of the intergranular fracture surface in the crack initiation zone was clearly higher for the fatigue-corrosion tests, confirming the synergistic effect between the fatigue and corrosion mechanisms. The interaction between fatigue and corrosion seemed to modify or favor some modes of failure.

Concerning the T9 metallurgical state, no difference was observed compared to tests performed on healthy and pre-corroded samples. The crack initiation was localized on a small corrosion defect, i.e., a pit, comparable to the pit generated by pre-corrosion treatment, and a main intergranular rupture mode in the propagation zone was still observed. The proportion of intergranular rupture mode is slightly more pronounced for fatigue-corrosion tests, i.e., $22 \%$, than for tests performed on pre-corroded samples, 
Table 3

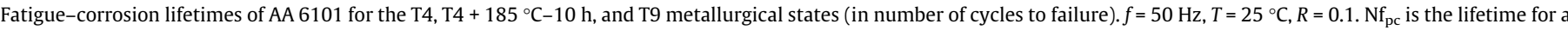
pre-corroded sample, $\mathrm{Nf}_{\mathrm{nc}}$ the lifetime for a non-corroded sample and $\mathrm{Nf}_{\mathrm{fc}}$ the lifetime for a fatigue-corrosion sample.

\begin{tabular}{|c|c|c|c|c|}
\hline & Non-corroded samples & Fatigue-corrosion samples & $\mathrm{Nf}_{\mathrm{fc}} / \mathrm{Nf}_{\mathrm{nc}}$ ratios & Ratios \\
\hline \multicolumn{5}{|l|}{ T4 } \\
\hline$\sigma=95 \%$ of UTS & $400 \times 10^{3} \pm 130 \times 10^{3}$ & $254 \times 10^{3} \pm 140 \times 10^{3}$ & $0.58 \pm 0.16$ & $0.7 \pm 0.3$ \\
\hline$\sigma=89 \%$ of $U T S$ & $580 \times 10^{3} \pm 265 \times 10^{3}$ & $348 \times 10^{3} \pm 193 \times 10^{3}$ & $0.56 \pm 0.08$ & $0.7 \pm 0.3$ \\
\hline$\sigma=82.5 \%$ of UTS & $9407 \times 10^{3} \pm 1185 \times 10^{3}$ & $712 \times 10^{3} \pm 217 \times 10^{3}$ & $0.07 \pm 0.02$ & $0.8 \pm 0.2$ \\
\hline \multicolumn{5}{|l|}{$\mathrm{T} 4+185^{\circ} \mathrm{C}-10$} \\
\hline$\sigma=95 \%$ of UTS & - & - & - & - \\
\hline$\sigma=89 \%$ of $U T S$ & $100 \times 10^{3} \pm 13 \times 10^{3}$ & $49 \times 10^{3} \pm 10 \times 10^{3}$ & $0.48 \pm 0.04$ & $0.66 \pm 0.33$ \\
\hline$\sigma=82.5 \%$ of UTS & $186 \times 10^{3} \pm 50 \times 10^{3}$ & $43 \times 10^{3} \pm 6 \times 10^{3}$ & $0.24 \pm 0.03$ & $0.8 \pm 0.2$ \\
\hline \multicolumn{5}{|l|}{ T9 } \\
\hline$\sigma=95 \%$ of UTS & $836 \times 10^{3} \pm 721 \times 10^{3}$ & $295 \times 10^{3} \pm 40 \times 10^{3}$ & $0.35 \pm 0.06$ & $0.32 \pm 0.3$ \\
\hline$\sigma=89 \%$ of $U T S$ & $2295 \times 10^{3} \pm 1216 \times 10^{3}$ & $516 \times 10^{3} \pm 126 \times 10^{3}$ & $0.27 \pm 0.09$ & $0.08 \pm 0.06$ \\
\hline$\sigma=82.5 \%$ of UTS & $11588 \times 10^{3} \pm 8572 \times 10^{3}$ & $912 \times 10^{3} \pm 87 \times 10^{3}$ & $0.16 \pm 0.11$ & $0.14 \pm 0.06$ \\
\hline
\end{tabular}

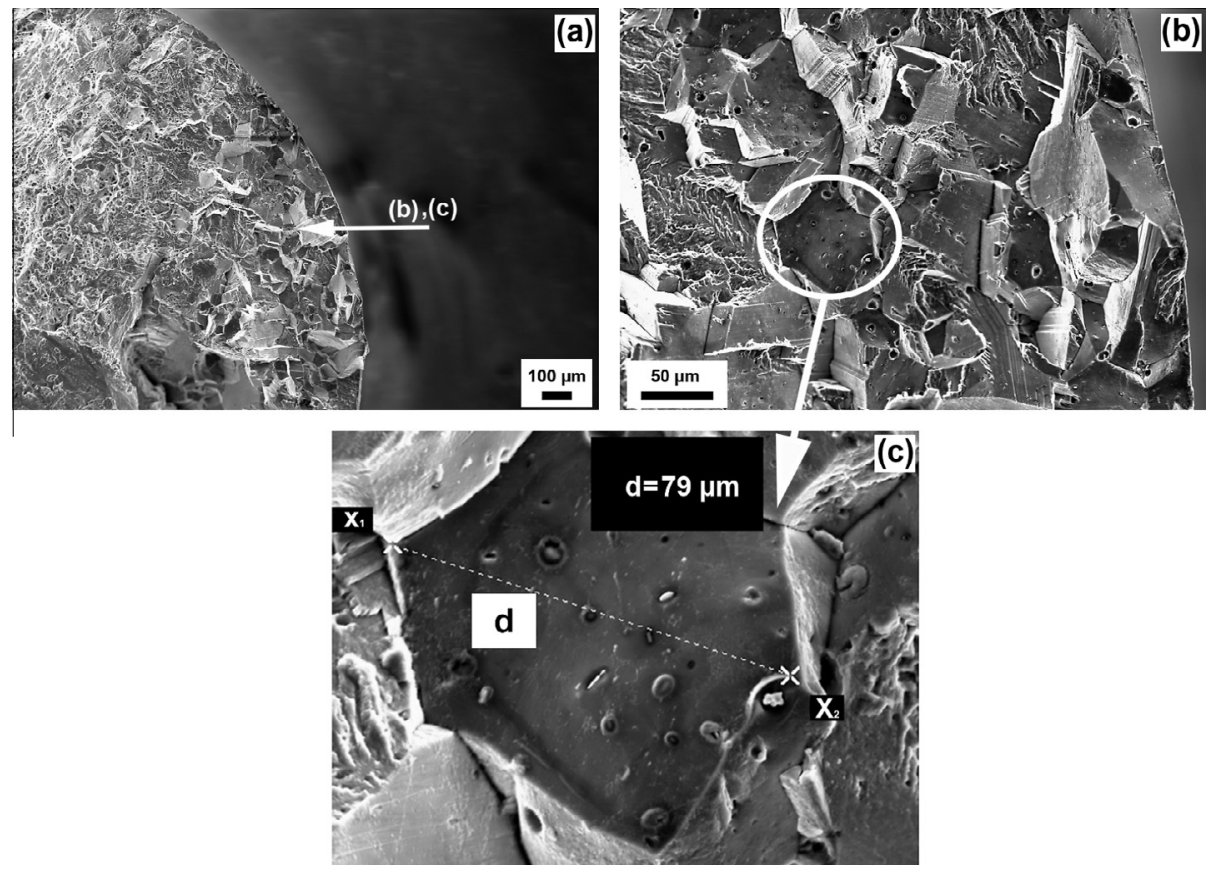

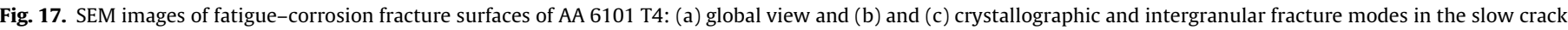
propagation zone, respectively. Line (d) shows a measurement of the intergranular surface dimension.

i.e., $19 \%$, but it is difficult to strictly state owing to the nanoscale of the microstructure.

Finally, the fatigue-corrosion interactions have shown a decrease of the fatigue life of the T4 and $\mathrm{T} 4+185^{\circ} \mathrm{C}-10 \mathrm{~h}$ metallurgical states resulting in the appearance or the reinforcement of an intergranular rupture mode. By contrast, according to the fracture surface observations, T9 metallurgical state seemed not to induce fatigue-corrosion interactions. The role of this synergistic effect on intergranular rupture mode could suggest an hydrogen embrittlement mechanism or at least a fatigue crack propagation assisted by hydrogen. Many studies have demonstrated that fatigue behavior of aluminum alloys could strongly be influenced by hydrogen produced by corrosion reactions or contained in water vapor $[48,49]$. This point will be discussed in more detail in the following section.

\subsection{Synergistic effect of corrosion and fatigue phenomena}

At first sight, the results obtained from the fatigue-corrosion tests suggested that the interaction between fatigue and corrosion decreased the fatigue endurance for the $\mathrm{T} 4$ and $\mathrm{T} 4+185^{\circ} \mathrm{C}-10 \mathrm{~h}$ metallurgical states and affected the fracture modes. However, this interaction seemed not to affect the fatigue-corrosion behavior of the T9 metallurgical state.

To obtain a better understanding of the synergistic effect between fatigue and corrosion, additional experiments were performed for the T4 samples. The results helped explain the observations for the other metallurgical states.

\subsubsection{AA 6101 T4 metallurgical state}

Previous results suggested that the synergistic effect between corrosion and fatigue phenomena resulted in the appearance of an intergranular failure mode. To confirm this assumption, two stress corrosion cracking (SCC) tests were conducted. The main objective of these tests was to verify whether a static mechanical loading could induce a modification of the failure mode as a fatigue-corrosion interaction. The first type of tests was low strain rate tensile tests in aggressive solution. These tests consisted of tensile tests performed in corrosive media for different exposure times corresponding to the fatigue-corrosion test times, i.e., 

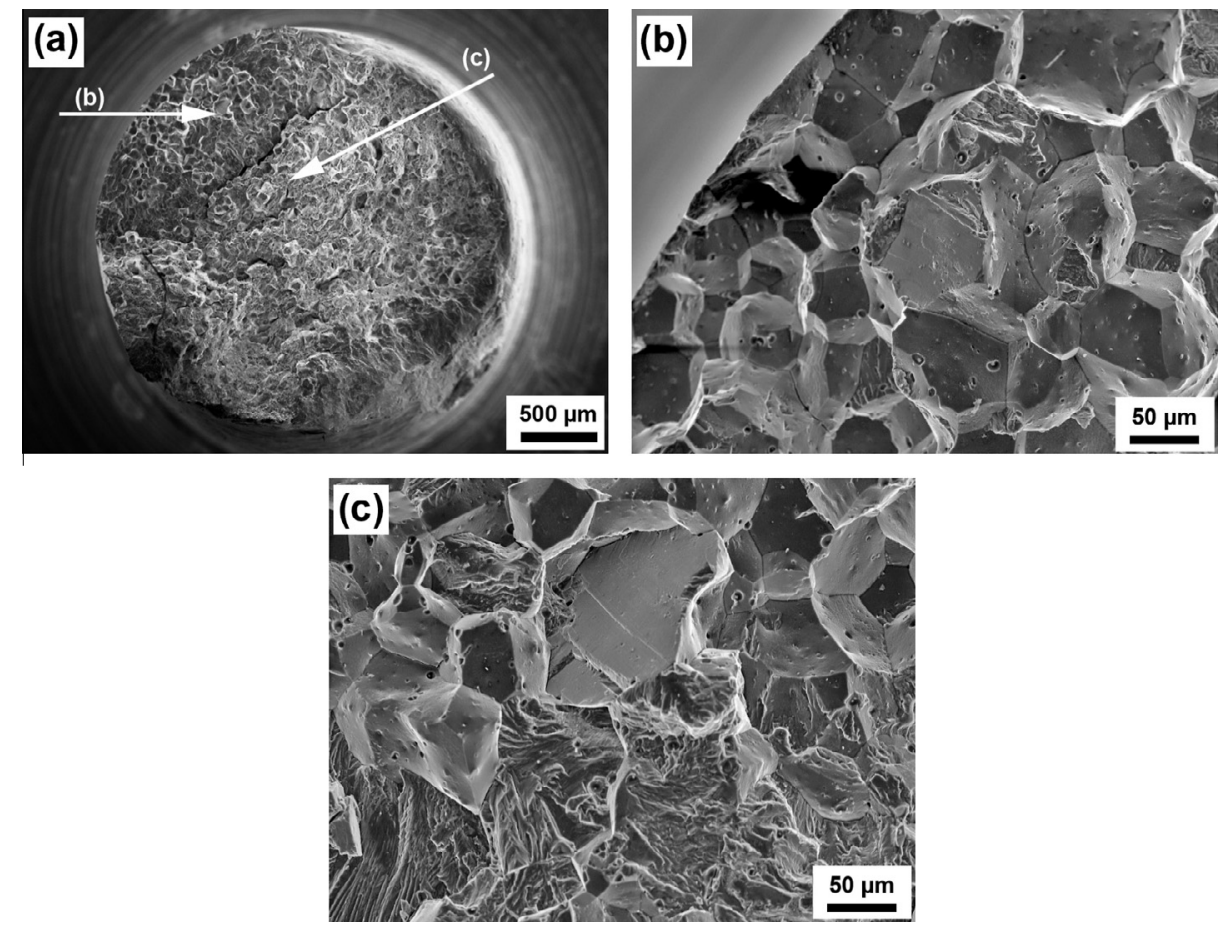

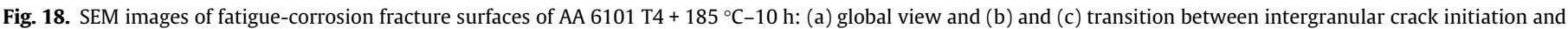
transgranular crack propagation.

$1.5 \mathrm{~h}, 2 \mathrm{~h}$, and $4 \mathrm{~h}$. The tensile test times were adjusted by varying the strain rate, i.e., $6.5 \times 10^{-5} \mathrm{~s}^{-1}, 4.8 \times 10^{-5} \mathrm{~s}^{-1}$, and $2.4 \times 10^{-5} \mathrm{~s}^{-1}$ estimated based on preliminary tensile tests. These preliminary tensile tests performed in air revealed, in particular, that the tensile behavior of AA 6101 T4 was not dependent on the strain rate. The results of the low-strain-rate tensile tests in $\mathrm{NaCl}$ solution showed that the tensile behavior of AA $6101 \mathrm{~T} 4$ was not affected by the corrosive medium, as its mechanical properties the same as those obtained from tensile tests performed in air regardless of the strain rate, i.e., regardless of the duration of the exposure to the chloride-containing solutions. Moreover, the fracture surfaces obtained after the tensile tests, regardless of exposure time, exhibited ductile rupture and not intergranular rupture, as observed in Fig. 19.

The second test consisted of maintaining a tensile sample under a stress equal to the stress level applied during fatigue endurance tests (89\% of UTS) and for a similar exposure time to corrosive media. These SCC tests under constant loading were stopped after 4 days without the rupture of the samples that confirms that the AA 6101 T4 is not susceptible to stress corrosion cracking according to results of literature on 6xxx series aluminum alloys [50].
Therefore, the SCC tests confirmed that the appearance of an intergranular failure mode during fatigue-corrosion tests was due to an interaction between these two mechanisms, i.e., fatigue and corrosion.

Based on these results, the synergistic effect between fatigue and corrosion could be discussed. Intergranular failure was generally related to a decrease in the grain boundary cohesive energy, which could be generated by chemical or mechanical phenomena. One such chemical phenomenon is intergranular corrosion. However, corrosion tests showed that the T4 metallurgical state was not susceptible to intergranular corrosion. Another mechanism was required to explain these observations. A potential fatiguecorrosion mechanism could be based on hydrogen embrittlement (HE). Indeed, it has been shown in a previous work that hydrogen issued from corrosion reactions could penetrate into the material and diffuse preferentially in the grain boundaries [51] and finally be trapped in the plastic zone at the crack tip. One possible HE mechanism was the hydrogen-enhanced mechanism (HEDE). This mechanism was first suggested by Troiano $[52,53]$ and developed in detail by Oriani $[54,55]$. The authors proposed that hydrogen accumulated within the lattice and there reduced the cohesive
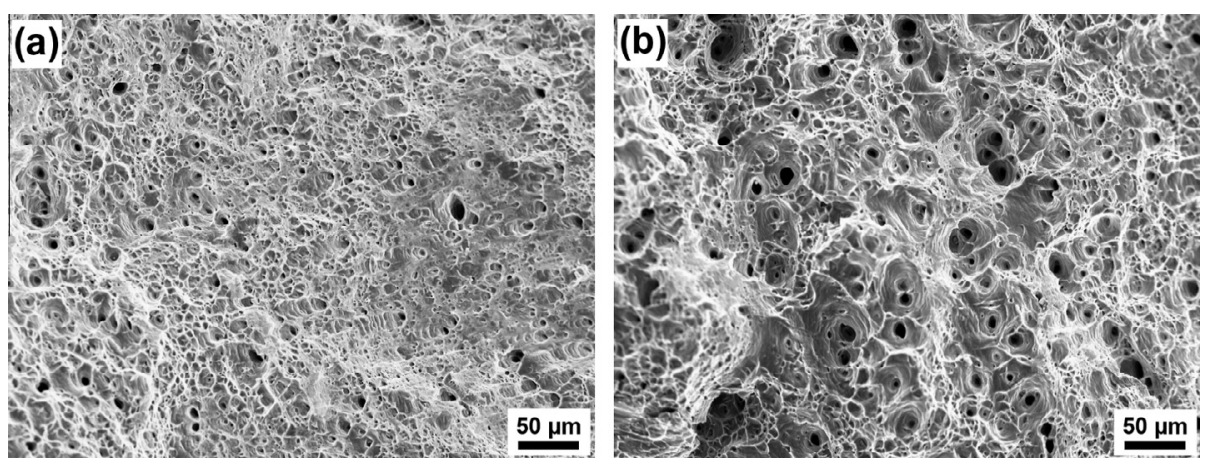

Fig. 19. SEM images of AA $6101 \mathrm{~T} 4$ after (a) a tensile test performed in air at $6.5 \times 10^{-5} \mathrm{~s}^{-1}$ and (b) a tensile test performed in a $0.5 \mathrm{M} \mathrm{NaCl}$ solution at $6.5 \times 10^{-5} \mathrm{~s}^{-1}$. 
bonding strength between metal atoms. The HEDE mechanism suggested that hydrogen damage occurred in the crack tip fracture process zone (FPZ) when the local crack tip opening tensile stress exceeded the maximum local atomic cohesion strength, lowered by the presence of hydrogen. The propagation of the crack could occur by cleavage at precipitates or dispersoid/matrix interfaces (no intergranular precipitates are present in the T4 metallurgical state), along grain boundaries enriched in hydrogen and favorably oriented, along slip bands or through cyclically developed dislocation structures (LEDS) ahead of the crack tip [56,57]. Cyclic plastic deformation accumulation along grain boundaries could be associated with an hydrogen transport mechanism by dislocations giving rise to an hydrogen enrichment of the grain boundaries enhancing the intergranular rupture. This hydrogen transport mechanism could be favored by the presence of PFZ around grain boundaries for $\mathrm{T} 4+185^{\circ} \mathrm{C}-10 \mathrm{~h}$ metallurgical state.

Moreover the stability of the passive film at the crack tip is a parameter to take into account. Generally, the rupture of the passive film under fatigue-corrosion conditions is related to the combination of an environmental and a mechanical effect. The low $\mathrm{pH}$ and a high chloride concentration can lead to the destabilization of the passive film at the crack tip as well as the fracture of the passive film due to cyclic loading. As described by Staehle [58], there is a competition between the strain rate at the crack tip and the repassivation rate. If the repassivation rate is too fast, the crack propagation is stopped. However, if the repassivation rate is too low, the crack can also be stopped by crack tip blunting due to generalized corrosion. When the crack tip is depassivated, it acted as an anodic site relative to the cathodic behavior of the crack walls that increases the hydrogen production $[59,60]$ inducing an hydrogen-assisted propagation as described by several authors for aluminum alloys $[37,61,62]$.

To validate such a hydrogen embrittlement mechanism, local analysis must be performed to detect hydrogen and localize it. In a previous work, this type of detection was conducted with success by means of combined Kelvin probe force microscopy and secondary ion mass spectrometry analysis $[63,64]$. Finally, to estimate the real contribution of hydrogen on fatigue crack propagation in addition to the effect on initiation step, it would be necessary to run da/ dN vs. $\Delta K$ tests for both air and $\mathrm{NaCl}$ media.

The detection of hydrogen in AA 6101 alloy submitted to fatigue-corrosion tests and a study focused on the stress conditions at the tip of the corrosion defects will be topics of future research.

\subsubsection{AA $6101 \mathrm{~T} 4+185^{\circ} \mathrm{C}-10 \mathrm{~h}$ metallurgical state}

For this metallurgical state, the fatigue-corrosion interaction favored intergranular failure. This observation could be explained by analogous mechanisms described previously, exacerbated by the presence of PFZ which promoted the localization of the strain and perhaps the hydrogen transport along grain boundaries [40].

\subsubsection{AA 6101 T9 metallurgical state}

At first sight, it could be concluded that this metallurgical state was not susceptible to fatigue-corrosion interactions. It is probably due to a very fast crack initiation on corrosion defect whose size is not negligible compared to the wire diameter. Apparently fatiguecorrosion interactions did not have effect on the propagation step.

\section{Conclusions}

The fatigue behavior of AA 6101 under $\mathrm{T} 4, \mathrm{~T} 4+185^{\circ} \mathrm{C}-10 \mathrm{~h}$, and $\mathrm{T} 9$ metallurgical states was studied in air for healthy and pre-corroded samples. The results were compared to those obtained during fatigue-corrosion tests in $\mathrm{NaCl}$ solutions.
In air, the heat treatment led to a strong decrease in the fatigue endurance of the material due to the formation of PFZ and $\mathrm{Mg}_{2} \mathrm{Si}$ intergranular precipitates, which promoted intergranular failure. The complete wire drawing process seemed to increase the fatigue properties of AA 6101 by decreasing the grain size.

The pre-corrosion heat treatment led to a decrease in the number of cycles to failure for a given stress level regardless of the metallurgical state, which could be explained by premature crack initiation on corrosion defects but without the modification of the failure modes during the crack propagation regime. In this case, the T9 samples evidenced lower fatigue properties than the T4 samples, which could be related to a critical size of corrosion defects compared to the size of wire diameter.

The fatigue-corrosion tests showed a strong interaction between cyclic mechanical stresses and corrosive media for T4 and $\mathrm{T} 4+185^{\circ} \mathrm{C}-10 \mathrm{~h}$. The modification of the failure mode observed could be explained by a hydrogen embrittlement mechanism induced by corrosion reactions and then enhanced by the plasticity state at the crack tip and microgalvanic coupling.

\section{Acknowledgments}

This work was financially supported by LEONI Wiring Systems, France. The material was provided by Rio Tinto Alcan and cold drawn by SASA Trefil'Alu. The authors thank Didier Albert (Rio Tinto Alcan), Louis Chretien (LEONI Wiring Systems), and Jean-Jacques Zyla (SASA Trefil'Alu). The authors also thank Marie-Christine Lafont for the TEM observations.

\section{References}

[1] Chen GS, Wan KC, Gao M, Wei RP, Flournoy TH. Transition from pitting to fatigue crack growth-modeling of corrosion fatigue crack nucleation in a 2024T3 aluminum alloy. Mater Sci Eng A 1996;219:126-32.

[2] Zupanc U, Grum J. Effect of pitting corrosion on fatigue performance of shotpeened aluminium alloy 7075-T651. J Mater Process Technol 2010;210:1197-202

[3] Wang QY, Kawagoishi N, Chen Q. Effect of pitting corrosion on very high cycle fatigue behaviour. Scripta Mater 2003;49:711-6.

[4] DuQuesnay DL, Underhill PR, Britt HJ. Fatigue crack growth from corrosion damage in 7075-T6511 aluminium alloy under aircraft loading. Int J Fatigue 2003;25:371-7

[5] Kim S, Burns JT, Gangloff RP. Fatigue crack formation and growth from localized corrosion in Al-Zn-Mg-Cu. Eng Fract Mech 2009;76:651-67.

[6] Roklin SI, Kim JY, Nagy H, Zoofan B. Effect of pitting corrosion on the fatigue crack initiation and fatigue life. Eng Fract Mech 1999;62:425-44.

[7] Van der Walde K, Hillberry BM. Initiation and shape development of corrosionnucleated fatigue cracking. Int J Fatigue 2007;29:1269-81.

[8] Kermanidis AT, Petroyiannis PV, Pantelakis SpG. Fatigue and damage tolerance behaviour of corroded 2024 T351 aircraft aluminum alloy. Theory Appl Fract Mech 2005;43:121-32.

[9] Gruenberg KM, Craig BA, Hillberry BM, Bucci RJ, Hinkle AJ. Predicting fatigue life of pre-corroded 2024-T3 aluminum from breaking load tests. Int J Fatigue 2004;26:629-40.

[10] Shi P, Mahadevan S. Corrosion fatigue and multiple site damage reliability analysis. Int J Fatigue 2003;25:457-69.

[11] Dolley EJ, Lee B, Wei RP. The effect of pitting corrosion on fatigue life. Fatigue Fract Eng Mater 2000;23:555-60.

[12] Burns JT, Kim S, Gangloff RP. Effect of corrosion severity on fatigue evolution in Al-Zn-Mg-Cu. Corros Sci 2010;52:498-508.

[13] Liao M, Renaud G, Bellinger NC. Fatigue modeling for aircraft structures containing natural exfoliation corrosion. Int J Fatigue 2007;29:677-86.

[14] Pauze N. Ph.D. thesis: Fatigue corrosion dans le sens travers court de tôles d'aluminium 2024-T351 présentant des défauts de corrosion localisée. ENSM Saint-Etienne: France; 2008.

[15] Chlistovsky RM, Heffernan PJ, DuQuesnay DL. Corrosion-fatigue behaviour of 7075-T651 aluminum alloy subjected to periodic overloads. Int J Fatigue 2007;29:1941-9.

[16] Rebiere M, Magnin T. Corrosion fatigue mechanisms of an $8090 \mathrm{Al}-\mathrm{Li}-\mathrm{Cu}$ alloy. Mater Sci Eng A 1990;128:99-106.

[17] Rokhlin SI, Kim J, Nagy H, Zoofan B. Effect of pitting corrosion on fatigue crack initiation and fatigue life. Eng Fract Mech 1999;62:425-44.

[18] Horner DA, Connolly BJ, Zhou S, Crocker L, Turnbull A. Novel images of the evolution of stress corrosion cracks from corrosion pits. Corros Sci 2011;53:3466-85. 
[19] Pao PS, Gill SJ, Feng CR. On fatigue crack initiation from corrosion pits in 7075T7351 aluminum alloy. Scripta Mater 2000;43:391-6.

[20] Burns JT, Larsen JM, Gangloff RP. Driving forces for localized corrosion-tofatigue crack transition in $\mathrm{Al}-\mathrm{Zn}-\mathrm{Mg}-\mathrm{Cu}$. Fatigue Fract Eng Mater 2011;34:745-73.

[21] Mutombo K, du Toit M. Corrosion fatigue behaviour of aluminium alloy 6061T651 welded using fully automatic gas metal arc welding and ER5183 filler alloy. Int J Fatigue 2011;33:1539-47.

[22] Laurino A, Andrieu E, Harouard J-P, Odemer G, Blanc C. Effect of the thermomechanical history on the corrosion behavior of 6101 aluminummagnesium-silicon-iron alloy in $\mathrm{NaCl}$ solutions. ECS Trans 2012;41(25):93-105.

[23] Ambat R, Davenport AJ, Scamans GM, Afseth A. Effect of iron-containing intermetallic particles on the corrosion behaviour of aluminium. Corros Sci 2006;48:3455-71.

[24] Mondolfo LF. Aluminum alloys: structure and properties. London: Butterworths \& Co. Ltd.; 1976.

[25] Liu YL, Kang SB, Kim HW. The complex microstructures in an as-cast Al-Mg-Si alloy. Mater Lett 1999;41:267-72.

[26] Karabay S, Yilmaz M, Zeren M. Investigation of extrusion ratio effect on mechanical behavior of extruded alloy AA-6101 from the billets homogenisedrapid quenched and as-cast conditions. J Mater Process Technol 2005;160:138-47.

[27] Buchheit RG. A compilation of corrosion potentials reported for intermetallic phases in aluminum alloys. J Electrochem Soc 1995;142:3994-6.

[28] Blanc C, Roques Y, Mankowski G. Application of phase shifting interferometric microscopy to studies of the behavior of coarse intermetallic particles in 6056 aluminum alloy. Corros Sci 1998;40:1019-35.

[29] Eckermann F, Suter T, Uggowitzerb PJ, Afseth A, Schmutz P. The influence of $\mathrm{MgSi}$ particle reactivity and dissolution processes on corrosion in $\mathrm{Al}-\mathrm{Mg}-\mathrm{Si}$ alloys. Electrochim Acta 2008;54:844-55.

[30] Mizuno K, Nylund A, Olefjord I. Surface reactions during pickling of an aluminum-magnesium-silicon alloy in phosphoric acid. Corros Sci 2001;43:381-96.

[31] Szklarska-Smialowska Z. Pitting corrosion of aluminum. Corros Sci 1999;41:1743-67.

[32] Ezuber H, El-Houd A, El-Shawesh F. A study on the corrosion behavior of aluminum alloys in seawater. Mater Des 2008;29:801-5.

[33] Edwards GA, Stiller K, Dunlop GL, Couper MJ. The precipitation sequence in $\mathrm{Al}-$ Mg-Si alloys. Acta Mater 1998;46:3893-904.

[34] Gupta AK, Lloy DJ, Court SA. Precipitation hardening processes in an Al$0.4 \% \mathrm{Mg}-1.3 \% \mathrm{Si}-0.25 \%$ Fe aluminum alloy. Mater Sci Eng A 2001;301:140-6.

[35] Pang JC, Li SX, Wang ZG, Zhang ZF. General relation between tensile strength and fatigue strength of metallic materials. Mater Sci Eng A 2013;564:331-41.

[36] Lee YL, Pan J, Hathaway RB, Barkey ME. Fatigue testing and analysis (theory and practice). Amsterdam, Boston, Heidelberg: Elsevier Butter-worth Heinemann; 2005.

[37] Petit J, Sarrazin-Baudoux C. Some critical aspects of low rate fatigue crack propagation in metallic materials. Int J Fatigue 2010;32:962-70.

[38] Burns JT, Larsen JM, Gangloff RP. Effect of initiation feature on microstructurescale fatigue crack propagation in $\mathrm{Al}-\mathrm{Zn}-\mathrm{Mg}-\mathrm{Cu}$. Int $\mathrm{J}$ Fatigue 2012;42:104-21.

[39] Ro Y, Agnew SR, Bray GH, Gangloff RP. Environment-exposure-dependent fatigue crack growth kinetics for Al-Cu-Mg/Li. Mater Sci Eng A 2007;468470:88-97.

[40] Lütjering G, Albrecht J, Sauer C, Krull T. The influence of soft, precipitate-free zones at grain boundaries in $\mathrm{Ti}$ and $\mathrm{Al}$ alloys on their fatigue and fracture behaviour. Mater Sci Eng A 2007;56:2872-84.

[41] Yan A, Chen L, Liu H, Li X. Fatigue crack propagation behaviour and corrosion resistance of $\mathrm{Al}-\mathrm{Zn}-\mathrm{Mg}-\mathrm{Cu}-\mathrm{Ti}(-\mathrm{Sn})$ alloys. Mater Sci Technol 2013;29:319-25.
[42] Buffière JY, Savelli S, Jouneau PH, Maire E, Fougères R. Experimental study of porosity and its relation to fatigue mechanisms of model Al-Si7-Mg0.3 cast Al alloys. Mater Sci Eng A 2001;316:115-26.

[43] Zabett A, Plumtree A. Microstructural effects on the small fatigue crack behaviour of an aluminum alloy plate. Fatigue Fract Eng Mater 1995;18:801-9.

[44] Savelli S. PhD thesis. Identification des mecanismes et approche quantitative de la fatigue d'alliages modeles d'aluminium de moulage. INSA Lyon: France; 2000.

[45] Hertzberg RW. Deformation and fracture mechanics of engineering materials. 4 th ed. John Wiley \& Sons, Inc.; 2012; Hertzberg RW. Deformation and fracture mechanics of engineering materials. Int J Fatigue 2011;33:10-8.

[46] Höppel HW, May L, Prell M, Göken M. Influence of grain size and precipitation state on the fatigue lives and deformation mechanisms of $\mathrm{CP}$ aluminium and AA6082 in the VHCF-regime. Int J Fatigue 2011;33:10-8.

[47] Priester L. Joints de grains et plasticité cristalline. Traité Mécanique et Ingénierie des Matériaux, série Matériaux et Métallurgie. Eds Hermes/ Lavoisier; 2011.

[48] Petit J, Henaff G, Sarrazin-Baudoux C. Fatigue cracking and atmospheric environment. J Phys 2000;10:203-12.

[49] Wei RP, Gao M. Reconsideration of the superposition model for environmentally assisted fatigue crack growth. Script Met 1983:17:959-62.

[50] Braun R. On the stress corrosion cracking behaviour of 6XXX series aluminium alloys. Int J Mater Res 2010;101:657-68.

[51] Larignon C, Alexis J, Andrieu E, Odemer G, Blanc C. The contribution of hydrogen to the corrosion of 2024 aluminium alloy exposed to thermal and environmental cycling in chloride media. Corros Sci 2013;69:211-20.

[52] Troiano A. The role of hydrogen and other interstitials in the mechanical behavior of metals. ASM 1960;52:54-80.

[53] Johnson H, Morlet J, Troiano A. Hydrogen crack initiation and delayed failure in steel. Trans TMS-AIME 1958;212:528-36.

[54] Oriani R. The diffusion and trapping of hydrogen in Steel. Acta Metall 1970;18:147-57.

[55] Oriani R. A mechanistic theory of hydrogen embrittlement of steels. Ber Bunsenges, Phys Chem 1972;76:848-57.

[56] Martin ML, Fenske JA, Liu GS, Sofronis P, Robertson IM. On the formation and nature of quasi-cleavage fracture surfaces in hydrogen embrittled steels. Acta Mater 2011;59:1601-6.

[57] Ro Y, Agnew SR, Gangloff RP. Effect of environment on fatigue crack wake dislocation structure in Al-Cu-Mg. Metall Mater Trans A 2012;43:2275-92.

[58] Staehle RW. Stress corrosion cracking of Fe-Cr-Ni alloy systems. In: Scully JC, editor. Theory of stress corrosion cracking. Brussels: NATO Scientific Affairs Division; 1971. p. 222-88.

[59] Augustin C. PhD thesis. Prévision des cinétiques de propagation de défauts de corrosion affectant les structures en alliage d'aluminium 2024. INP Toulouse: France; 2008.

[60] Marcus P. Corrosion books: corrosion mechanisms in theory and practice. Mater Corros 2003;54:467-8.

[61] Wei RP, Simmons GW. Recent progress in understanding environment assisted fatigue crack growth. Int J Fatigue 1981;17:235-7.

[62] Henaff G, Marchal K, Petit J. On fatigue-crack propagation enhancement by a gaseous atmosphere - experimental and theoretical aspects. Acta Metall Matter 1995;43:2931-42.

[63] Larignon C, Alexis J, Andrieu E, Lacroix L, Odemer G, Blanc C. Combined Kelvin probe force microscopy and secondary ion mass spectrometry for hydrogen detection in corroded 2024 aluminium alloy. Electrochim Acta, http:// dx.doi.org/10.1016/j.electacta.2013.02.063, [Available online 20 February 2013].

[64] Larignon C, Alexis J, Andrieu E, Lacroix L, Odemer G, Blanc C. Investigation of Kelvin probe force microscopy efficiency for the detection of hydrogen ingress by cathodic charging in an aluminium alloy. Scripta Mater 2013;68:479-82. 